\title{
Eutychianorum furor! Heresiological Comparison and the Invention of Eutychians in Leo I's Christological Polemic
}

\author{
SAMUEL COHEN \\ Sonoma State University, Department of History, United States of America
}

\begin{abstract}
This essay examines the use of heresiological rhetoric in the letters and tractates of Leo I (bishop of Rome, 440-461) written in defense of the Council of Chalcedon (451). In these texts, Leo claimed the Constantinopolitan monk Eutyches and his supporters, the Eutychians, were an existential threat to the faith. However, Leo's Eutychians were a heresiological confabulation. Heresiology employs polemical comparison and hostile classification to demarcate the boundaries of authentic Christianity. Because heresiology understands heresy genealogically, contemporary error could be described and condemned thanks to its affiliation with previous heretical sects. This was largely a taxonomic exercise; naming heresies allowed their supposed errors to be categorized and compared, especially with its (imagined) antecedents. Leo employed precisely this kind of comparison to associate Eutyches with earlier heresiarchs. He then reduced all opposition to Chalcedon to 'Eutychianism,' the error named for Eutyches, or else to its opposite and equally incorrect counterpart 'Nestorianism'-both of which were, according to Leo, part of the same diabolically inspired misunderstanding of Christ. In short, Leo transformed Eutyches, the man, into a 'hermeneutical Eutychian,' a discursive construct intended to advance Leo's own theological agenda, especially the creation of an orthodox identity coterminous with adherence to Chalcedon.
\end{abstract}

KEYWORDS heresiology, Christological Controversy, Papacy/Bishops of Rome, Leo I, rhetoric, Eutyches, Late Antiquity

\section{Introduction}

In September 457, Leo I, bishop of Rome (440-461), wrote a lengthy letter to several eastern bishops including Basil of Antioch, Euxitheus of Thessalonica, and Juvenal of Jerusalem. ${ }^{1}$ His topic was ostensibly the murder earlier that year of Proterius, bishop of Alexandria. But the

1 I would like to thank Richard Flower, Christina Brauner, Sita Steckel, Julie Anderson, Emily Ray, and the two anomymous reviewers for their comments and suggestions. 
letter's greater purpose was to defend the orthodoxy of the Council of Chalcedon (451). The council had been intended to resolve the Christological Controversy, which divided Christians over the understanding of the relationship between Christ's divine and human natures. Unfortunately, the Chalcedonian settlement provoked widespread, sometimes violent, opposition especially in the eastern Mediterranean. Antagonism to the council was particularly strong amongst Alexandrian Christians, many of whom refused to recognize the Chalcedonian Proterius as their bishop; instead, they had remained loyal to Dioscorus, who had been deposed at the council, and after his death in 454, to Timothy Aeluros, who succeeded Dioscorus as the non-Chalcedonian Patriarch of the city. ${ }^{2}$ Factionalism in Alexandria came to a head in 457 when a mob, possibly at Timothy's instigation, brutally lynched Proterius, desecrated his body, and incinerated it in the city's hippodrome. ${ }^{3}$ As Leo's letter explained, the murder had been perpetrated "by the fury of the Eutychians" (Eutychianorum furore), whose goal was to overturn Chalcedon and thereby to overthrow the whole of the Christian religion. But Leo was not about to let that happen on his watch. Chalcedon had to be protected, and, as he exhorted the bishops, the Eutychians had to be opposed. ${ }^{4}$ But who exactly were these murderous $E u-$ tychians? According to Leo, they were a perfidious heretical sect threatening the integrity of the orthodox tradition. With grim humorlessness, Leo repeatedly condemned the Eutychian heresy in his letters and tractates until his death in 461. And his successors would likewise take up the fight, ultimately elevating Eutychianism into the pantheon of Late Antiquity's most dangerous heresies. But Eutychians-a discrete group of devotees to the theological position advocated by Eutyches-never existed, at least not in the way described by Leo. Nor was Chalcedon the perfect expression of the Christian tradition. ${ }^{5}$ Rather, 'Chalcedonian orthodoxy' and 'Eutychian heresy' were discursive rather than historical objects, which emerged as part of the process by which that tradition was debated and defined. ${ }^{6}$ And crucially, when Leo wrote this letter to the eastern bishops, the debate was far from settled. ${ }^{7}$

The following abbreviations have been used: ACO = Eduard Schwartz, ed., Acta Conciliorum Oecumenicorum, series prima, Berlin \& Leipzig, 1914-1940; CCCL 138 = Antoine Chavasse, ed., Sancti Leonis Magni Romani pontificis tractatus septem et nonaginta, in CCSL 138-138a. 2 vols: Turnhout, 1973; CTh = Theodosiani Libri XVI cum Constitutionibus Sirmondianis, eds. Theodor Mommsen and Paul M. Meyer (Berlin, 1905); CJ = Codex Justinianus. ed. R. Krüger, Corpus luris Civilis II: Codex lustinianus (1963).

2 Timothy A'̉ toupos ('the Cat' or 'the Weasel'), Patriarch of Alexandria from 457-77, although in exile between 460 and 475 . His nickname was unsurprisingly used by his enemies more than by his supporters. See Ps.-Zachariah Rhetor, Chronicle (ed. Greatrex 2011, 130, n. 4 with refs).

3 On the violence in Egypt following Chalcedon, see Gregory (1979, 181-92).

4 To Basil, Bishop of Antioch, ep. 149 (ACO 2.4, 97-98); to Euxitheus of Thessalonica, Juvenal of Jerusalem, Peter of Corinth and Luke of Dyrrhachium, ep. 150 (after the introduction, the same text as was sent to Basil): "[...] cognitis quae apud Alexandriam Eutychianorum furore commissa sunt [...]".

5 On the evolution and definition of what constituted the Christian tradition specifically as it relates to Chalcedon, see Gwynn (2009).

6 Iricinschi/Zellentin (2008, 7); Le Boulluec (1985, II:10-19). In a slightly different context, see Boyarin (2007, 3); King (2008, 28); Williams (1989, 9). As Maurice Wiles (1991, 201), explains, "Heresy is not deviation from an already implicitly known truth, which orthodoxy preserves by the process of rendering it explicit at the points under challenge from heresy. Orthodoxy and heresy are rather alternative possible developments of an initially inchoate and variegated movement."

The Christological Controversy-specifically, the validity of Chalcedon-continued to be debated into the seventh century. Eastern emperors made various attempts to unify Christians after Chalcedon, beginning with Zeno's Henotikon in 482 and ending with the Council of Constantinople III in 681. Today, Chalcedon is accepted as authoritative by the Catholic and Eastern Orthodox churches, as well as most mainline Protestant denominations. It is rejected by Oriental Orthodox Christians ('miaphysites') such as the Coptic, Syriac (or 'Jacobite'), Armenian, and Ethiopic churches, as well as by the Assyrian Church ('Nestorian' Christians). For an overview of the reception of Chalcedon, see, for instance, Grillmeier (1986, 195-236) and the essays collected in Mühlenberg (1997); for Christianity in the east after Chalcedon, see Meyendorff (1989, 251-92, 333-73). 
Eutyches (c. 380-c. 454), the supposed founder of Eutychianism, was a Constantinopolitan archimandrite who played a central role in rekindling the Christological Controversy in the late 440s and was eventually condemned for heresy in 448 by Flavian, Patriarch of Constantinople (446-449). As we shall see in Part One of this essay, Leo exchanged several letters with Eutyches and only gradually came to view him as a threat to orthodoxy, which Leo predictably defined as adherence to his own Christology. Events moved quickly following Eutyches' condemnation. The Second Council of Ephesus in 449 exonerated Eutyches. Two years later and after a series of sessions that included considerable debate, the Council of Chalcedon (451) reversed the decisions made at Ephesus, reconfirmed Eutyches' condemnation, and adopted Leo's Christology as orthodox. To defend Chalcedon from its critics, Leo turned to heresiology, the 'science' of heresy-hunting. Like ancient ethnography, heresiology attempts to make sense of the world through comparison, classification, categorization, and by explaining the origins and histories of peoples and ideas (Berzon 2016, passim, but esp. 7-11, 27-29, 58-61). When Christian ethnographers of heresy, the heresiologists, identified heresy-that is, a theological position that departed from their own understanding of authentic Christian tradition-they endeavored to name it, to describe its history and essential attributes, to compare it to other errors, and ultimately to classify it through its (imagined) relationship with earlier heretical sects. Heresiology, then, was as concerned with taxonomy and genealogy as with theology; to put it slightly differently, correct and incorrect theology were thought to be explicable and distinguishable taxonomically and genealogically. In Part Two, I briefly consider the history of heresiology as well as the immediate context of Leo's particular brand of heresiological polemic, which emerged out of the earlier phase of the Christological Controversy.

Part Three, the main section of this essay, engages in a detailed examination of Leo's heresiological rhetoric in defense of Chalcedon, which consisted of several overlapping elements. First, heresiological comparison allowed Leo to link Eutyches' teachings with some of Christianity's most notorious heretics, including Mani, the founder of Manichaeism, Marcion of Sinope, a second-century thinker condemned for his radical dualism, and Apollinaris of Laodicea, who was condemned at the First Council of Constantinople in 381 for denying that Christ had a rational soul. Leo also equated Eutyches' error with that of his principal theological antagonist, Nestorius, Patriarch of Constantinople ( $d .451$ ), who had been deposed by the First Council of Ephesus in 431. According to the bishop of Rome, Eutyches and Nestorius were the two (opposite) extremes of Christological error, paradoxically united by their difference. Leo also came to view Eutyches as a heresiarch in his own right, the father of the sect of the 'Eutychians.' He then reduced all opposition to Chalcedon to 'Eutychianism' and less frequently to 'Nestorianism,' both of which were, in any case, part of the same diabolically inspired misunderstanding of Christ. Although not unique-the kind of hostile comparison employed by Leo was common in Christian controversial literature in this period-the large numbers of surviving Leonine letters and tractates makes this one of the best documented examples of this process in Latin. Moreover, it sheds important light on both the history of the Christological Controversy and the use of polemical comparison in the late antique West. In Part Four, I consider the effectiveness of Leo's anti-Eutychian writing, its audience and reception, and attempt to contextualize Leo's heresiological rhetoric within the wider literature of polemical comparison. Finally, the essay concludes by examining the legacy of Leo's polemic, particularly in Roman law. 


\section{Leo and Eutyches: Context and First Contact}

The sizeable surviving Leonine corpus-143 letters and 98 sermons, many of which deal with questions related to heresy and orthodoxy and specifically the Christological Controversyallows us to trace the development of Leo's Christological polemic with a fair degree of precision. ${ }^{8}$ Surprisingly, the first contacts between Leo and Eutyches were cordial. Sometime before June 448, Leo received a letter from Eutyches warning the bishop of Rome about the revival of the Nestoriana haeresis at Constantinople. ${ }^{9}$ The haeresis in question was that of Nestorius, Patriarch of Constantinople, who had come into conflict with Cyril of Alexandria (d. 444) almost two decades earlier over Christology: How could Christ be simultaneously God and man? ${ }^{10}$ Answers to this question occupied, according to one recent appraisal, "an almost unmanageably narrow space between Christ being too human and being too divine-and, conversely, between being not divine enough and being not human enough" (Ames 2015, 33). By the early part of the fifth century, two principal approaches to Christology emerged. The first, sometimes termed miaphysitism after the formula popularized by Cyril and (wrongly)

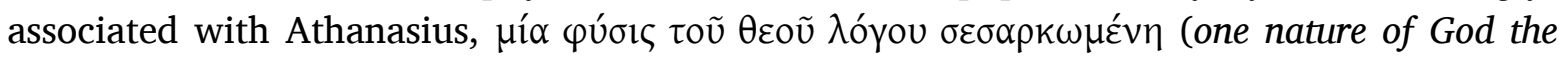
Word incarnate), emphasized the unity of the divine and human elements in the incarnate Christ (Louth 2015, 141). ${ }^{11}$ The second, unoriginally called dyophysitism by modern scholars ( $\delta$ v́ $\varphi v ́ \sigma \varepsilon \sigma i v$, two natures), included theologians such as Theodore of Mopsuestia, Theodoret of Cyrus, and, of course, Nestorius. These thinkers asserted that Christ's humanity had to be maintained as distinct and separate from his divinity, although they were united in a single person. ${ }^{12}$ The controversy came to a head in 428 when Nestorius objected to the term

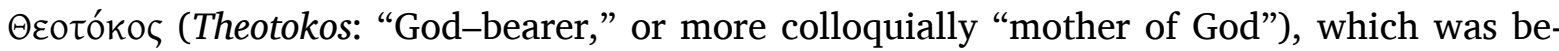
ing used by some Christians in Constantinople to describe Mary. Cyril and his supporters

$8 \quad$ According to the estimate of Fuhrmann and Jasper (2001, 41-42), of Leo's 143 genuine surviving letters, 112 can be classified as 'dogmatic.' The vast majority of these pertain to the Christological Controversy (after 451, the preservations of Chalcedon) and are principally addressed to eastern recipients. On the Leonine corpus, see also Neil (2016, 455-57); Silva-Tarouca (1926, 25); Casula (2002, 52-53, 57). On the structure of Leo's letters, see McShane (1979, 338-41); Blümer (1991). Leo's sermons survive principally in two collections, which circulated during his lifetime. The second collection is principally concerned with the Christologiocal Controversy and contains sermons preached between 452 and 454 with several additional sermons from between 446 and 461. See Neil (2009, 13-15).

9 Eutyches' first letter to Leo does not survive. Eutyches enjoyed a friendship with the eunuch Chrysaphius, who was influential from 441 until the last few months of Theodosius II's reign in 450.

10 The following description of the Christological Controversy is necessarily general. For a recent overview of the controversy and the scholarly opinions about it, see the essays collected in Murphy, ed. (2015).

11 Monophysitism (one nature) is also sometimes applied to this position. But modern scholars and the churches who adhere to this Christology generally prefer miaphysitism because it reflects the formula articulated by Cyril, although Louth $(2015,140)$, calls it a "barbarous coinage." See also van Loon (2009, 17-18, n. 12). Indeed, 'monophysitism,' 'miaphysitism,' and 'dyophysitism' (see n. 12 immediately below) group widely disparate Christological positions into neat categories, often for polemical rather than descriptive purposes. This plays directly into the kind of rhetorical constructivism that this paper is attempting to deconstruct. In what follows, I attempt to avoid these terms. When necessary, I have preferred to employ (intentionally) less technical-sounding phrases such as "one-nature" or "two-nature" Christology or their analogues, but even here the interested reader should endeavour to examine the Christology of each thinker in isolation rather than assuming that they can be reduced to an adherent of this or that theological school. Eutyches' Christology appears to have been a radicalized version of that advanced by Cyril, although scholarly debate on this point continues and is complicated by the fact that much about Eutyches, especially in Latin, comes from hostile sources. For a brief overview and an extensive bibliography, see Simonetti (2014, 826-29). On Cyril's teachings, see for example, Wessel (2004); McGuckin (2004); Boulnois (1994); Grillmeier (1975, 473-83); Frend (1979, 121-23). On the difficulties posed by Greek theological vocabulary, see Frend (1979, 2-3). On Eutyches' Christology, see below, n. 14.

12 On Nestorius' theology and that of his supporters, see Loofs (1914, passim but esp. 94ff); Schäublin (1974); Grillmeier (1975, 451-72); Simonetti (1985, 156-201); Di Berardino (2006); Gavrilyuk (2004, 141-44). 
argued that Nestorius' objection to the term, and his theology more generally, threatened to undermine the divinity of Christ, splitting him into two persons, human and divine (Price and Gaddis 2005, 17-19). The debate prompted the Emperor Theodosius II to call what became the First Council of Ephesus in 431. With Rome's support, Cyril and the council deposed Nestorius and condemned his teachings. But seventeen years later, at least according to Eutyches' letter to Leo, Nestorius' heresy was once again growing in the eastern capital. The bishop of Rome thanked Eutyches, whom he called "most beloved son" (dilectissimus filius), for making him aware of the threat to orthodoxy (ep. 20, ACO 2.4, 3).

Eutyches' letter to Leo reflects the divisions, which persisted in the wake of Ephesus I. Cyril and especially Dioscorus, who succeeded Cyril as bishop of Alexandria in 444, worked diligently to oppose any Christological positions that emphasised the separation of the natures, which they vilified with the label 'Nestorian' (Sillett 1999, passim, but esp. 2-40). Their opponents likewise continued to oppose the most radical iterations of Cyril's own Christological teaching. It was in this context that at the end of 448, Leo received a second missive from Eutyches appealing his condemnation for heresy. ${ }^{13}$ In the months following his initial letter to Rome, Eutyches had been denounced by Eusebius of Dorylaeum for denying Christ's humanity. ${ }^{14}$ His trial took place at the so-called Home Synod of November 448, a meeting of available bishops in Constantinople presided over by the Patriarch Flavian. At first, Flavian preserved an air of impartiality; but once Eutyches appeared to defend himself, the patriarch demanded the monk admit the orthodoxy of the phrase "two natures" (duae naturae in the Latin translation of Eutyches' letter to Leo)—a reference to the belief that Christ existed in two natures after the incarnation, human and divine-and to anathematize anyone who would not likewise agree. Eutyches claimed that he was not sure if this was orthodox. As a result, the synod condemned Eutyches, deposed him from the leadership of his monastery, and excommunicated him for holding the heresy of "Valentinus and Apollinaris." 15

That Eutyches had been condemned for heresy must have been surprising to Leo, who had not yet received any reports from Constantinople about the monk's supposed error. In his libellus appellationis to Leo, Eutyches portrayed himself as a simple monk attempting to adhere as closely as possible to the faith pronounced at the Council of Nicaea (325) and elucidated by the church fathers (parentes) such as Cyril and Athanasius. In response, Leo wrote to Flavian in February 449 to inquire as to why Rome had not yet been informed about the circumstances of Eutyches' condemnation (ep. 23, ACO 2.4, 4-5). ${ }^{16}$ Flavian had, in fact, already sent a full account of the Home Synod, but due to the vagaries of late antique communication, the letter would not arrive until the late spring of the following year. ${ }^{17}$

Once he read Flavian's letter, Leo's initial hesitancy was replaced by the conviction that Eutyches and his radical one-nature Christology (as Leo understood it) were heretical and had to be opposed. Modern scholars debate whether Eutyches deserves this reputation. For one, Flavian had misrepresented Eutyches' beliefs to Leo, and the bishop of Rome appears to have

13 Survives in two variants: Libellvs appellationis ad papam Leonem in ACO 2.2.1, 33-35; ACO 2.4, $143-145$.

14 On Eutyches' Christology (which was not static), see in particular Schwartz (1929, 1-93); Draguet (1931, 441-57). Vranić (2008). On Eutyches' trial, see Price/Gaddis (2005, 25-30). See also the assessment of Eutyches and his orthodoxy in Chadwick (2001, 561).

15 The acta of the Home Synod, along with significant portions of the acta from Ephesus II (449), were read into the record at Chalcedon. The sentence against Eutyches is preserved at ACO 2.3.1, 128. A narrative of the events between 448 and the Council of Chalcedon in 451 can be found in Price (2009). On the sociological aspects of the council, see Amirav (2015).

16 See also Leo's letter to Theodosius written on the same day, ep. 24 (ACO 2.4, 3-4).

17 Flavian's first letter to Leo, Relatio ad Papam Leonem de Damnatione Evtychis (ACO 2.2.1, 21-22); the second, alia epistola ad Papam Leonem de Evtychem (ACO 2.2.1, 23-24). 
further misunderstood the acta of the Home Synod as suggesting that Eutyches had denied the humanity of Christ (Price and Gaddis 2005, 1.116). ${ }^{18}$ Based on this misapprehension, Leo sent a flurry of letters in June 449 addressed to members of the imperial family, eastern bishops Julian of Cos and Juvenal of Jerusalem, and Flavian himself. This last letter was the Tomus ad Flavianum (ep. 28, ACO 2.2.1, 24-33), Leo's own Christological formulation that Christ was one person in two natures. ${ }^{19}$ The Tomus would have monumental ramifications for the Christological Controversy and the shape of late antique Christianity.

Even at this early phase in the controversy, Leo was a conscientious polemicist, modulating the nature and tone of his opposition to Eutyches depending on his audience. Writing to eastern bishops and the imperial family, he remained conciliatory. For example, in a letter to Emperor Theodosius' sister Pulcheria, Leo stated that Eutyches had fallen into error "from ignorance rather than guile" (ep. 31, ACO 2.4, 12-15, quoted at 12). ${ }^{20}$ Mirroring Eutyches' portrayal of himself in his second letter to Rome, Leo portrayed the monk as naïve and unsophisticated; he had fallen into error because his opposition to Nestorianism encouraged him to overemphasize Christ's divinity at the expense of his humanity. Should Eutyches denounce his error in writing, he could be rehabilitated and return to his monastery (ep. 31, ACO 2.4, 12-15, at 15). Similarly writing to Theodosius, the abbots of the Constantinopolitan monasteries, and bishops who had already begun to gather for what would become the Council of Ephesus II, Leo asserted that Eutyches' error resulted from ignorance and imprudence motivated by his zealous opposition to Nestorius. Thus, at least in his communications with the Greek east, the bishop of Rome remained hopeful that Eutyches and his supporters could be reconciled (ep. 29, ACO 2.4, 9-10). ${ }^{21}$ Even in the Tomus and in his letter to Theodosius, Eutyches is described as "rash and arrogant," and as an unsophisticated old man (imperitus senex) quite blind to the truth (ep. 29, ACO 2.4, 9-10, quoted at 9). ${ }^{22}$ This was certainly not a ringing endorsement; however, it is consistent with Leo's characterization of Eutyches as naïve rather than malevolent. In these letters too, Leo left open the possibility of reconciliation with Eutyches should he recant (ep. 28.6, ACO 2.2.1, 24-33).

But with confidants, Leo adopted a harsher tone. In a letter to Julian of Cos also written in June 449-that is, at the same time as the above letters to Theodosius and Pulcheria-Leo described Eutyches' error as tantamount to that of Nestorius, only inverted. This paradoxically connected Eutyches, a harsh critic of Nestorius, with Nestorius. Leo also compared Eutyches' theology to those of already condemned heretics. By denying the humanity of Jesus Christ, Leo tells Julian, Eutyches must be "filled with many impieties: either Apollinaris has conquered him, or Valentinus has seized him, or Mani has taken hold of him—none of whom believed

18 "The whole of his [Leo's] famous Tome," Leo's own Christological statement, "is vitiated by this mistake," according to Richard Price. One could push this even further: The Councils of Ephesus II and Chalcedon, and arguably the subsequent history of Christian theology, were in part animated by this misunderstanding. On Leo's Christology, see Wessel (2008, 209-57); Armitage (2005); Green (2008, 188-247); Grillmeier (1975, 526-39). Latin Christology is limited compared to the contribution made by theologians writing in Greek. See Grillmeier (1975, 392-413).

20 "[...] error qui arbitror de imperitia magis quam de uersutia natus est [[...] the error, which I believe was born out of ignorance rather than guile]."

21 See also Leo's letter to the bishops gathering for the Council of Ephesus (II), ep. 33 (ACO 2.4, 15-16), to abbots of Constantinople, ep. 32 (ACO 2.4, 11-12), to Faustus and Marinus, as well as other archimandrites in the east, ep. 32 (ACO 2.4, 11-12), and to Juvenal of Jerusalem (incorrectly identified as Julian of Cos in the PL and the ACO), which confirms that Leo was now convinced of Eutyches' guilt, ep. 34 (ACO 2.4, 16-17).

22 "[...] ut imperito seni ea in qua nimis caligat, veritas innotescat [[...] so that the truth, about which he is quite blind, might be made known to an ignorant old man]." He is also described as "blind" in the Tomus. 
the truth of Christ's human flesh" (ep. 35, ACO 2.4, 6-8, quoted at 6). ${ }^{23}$ For Leo, all of these heresiarchs maintained a similar, incorrect understanding of the nature of Christ's humanity. These assertions would eventually form the core of Leo's fully mature, anti-Eutychian polemic, as we shall see.

Events in the east would further radicalize Leo's polemic. In August 449, the Second Council of Ephesus (the Latrocinium, as Leo characterized it), took place under the presidency of Dioscorus of Alexandria with the support of several prominent eastern bishops and Theodosius (ep. 95, ACO 2.4, 50-51 quoted at 51). ${ }^{24}$ At the council, Dioscorus defended Eutyches as a champion of Cyrillian Christology and an uncompromising opponent of Nestorius. The result: Eutyches was reinstated; Leo's own Christological statement, the Tomus, was ignored; and Flavian was denounced and deposed as a crypto-Nestorian. ${ }^{25}$ The proceedings then degenerated into violence as soldiers and club-wielding monks enforced Dioscorus' pronouncements. The papal envoys, including the future bishop of Rome, Hilary, barely managed to escape unharmed. Flavian was not so lucky. He was badly injured and died in exile shortly after under suspicious circumstances (Price and Gaddis 2005, 31-33). If we believe the report related in Evagrius' History, Dioscorus personally beat him to death, although this is likely an exaggeration. ${ }^{26}$ It does, however, point to the chaotic and violent nature of the council (Chadwick 1955, 17-34).

When Leo learned what had occurred, he called a synod in Rome and annulled Ephesus II. ${ }^{27}$ But Dioscorus had the support of the emperor; the declaration of a Roman synod would not be enough to overturn the council. Thus, Leo challenged the council's decisions by negotiating directly with the imperial court and the patriarchal bishops, writing a flurry of epistles to them, to the clergy and monks of Constantinople, Rome's representatives in the eastern capital, and to the western imperial family (Wessel 2008, 260-61). As we shall see, heresiological comparison was an important aspect of Leo's rhetoric in these letters.

After Ephesus II, the situation evolved rapidly. Fatefully, Theodosius died in a hunting accident in the summer of 450. Pulcheria took control of the government and soon married the prominent general Marcian who, like his new wife, was sympathetic towards Leo's twonature Christology. Together (although Pulcheria appears to have been the driving force), they reversed Theodosius' religious policies and began preparations for what would eventually be

23 "negator enim mediatoris dei et hominum hominis Iesu Christi necesse est ut multis impietatibus impleatur, eumque aut Apollinaris sibi vindicet, aut Valentinus usurpet, aut Manichaeus obtineat, quorum nullus in Christo humanae carnis credidit veritatem [for it is necessary that he who denies Jesus Christ, the mediator between God and men, is man, must be implicated in many impieties: either Apollinaris claims him for himself, or Valentinus seizes him, or Mani holds him fast, none of whom believed the truth of human flesh in Christ]." See also Leo's letter to Juvenal of Jerusalem, noted above, ep. 34 (ACO 2.4, 16-17), in which Leo complains that Eutyches did not understand that his false beliefs are the "bonds with which the devil binds him."

24 The council was "non iudicium sed latrocinium... [not of judges, but of robbers]." For the larger political context of the controversy, see esp. Wessel (2008, 259-83).

25 Evagrius, Hist. Eccl. 1.10 (ed. Whitby 2000, 27-29). For an overview of the events at Ephesus II, see Price (2005, 30-37).

26 Evagrius, Hist. Eccl. 2.2 (ed. Whitby 2000, 60-62). Eusebius is said to have claimed that "Flavian had been wretchedly slain by being shoved and kicked by Dioscorus." However, it must be said that at Chalcedon, some of the bishops present also claimed that Dioscorus used or threatened violence and some even call him "murderer!"

27 October 13, 449, to Theodosius, from Leo and the Synod held at Rome, ep. 44 (ACO 2.4, 19-21). For a full narrative of the confused events of Ephesus II, see, for example, Grillmeier (1975, 526-29); Frend (1979, 38-45); Davis (1987, 176-80); McGuckin (2004); on the theological implications of the Council, see Pelikan (1978, 2:262-64). As Price and Gaddis (2005, 141, n. 79) note, it is unclear to what degree Ephesus II was any less free than other church councils. Coercion certainly occurred at Chalcedon as well. 
the Council of Chalcedon. ${ }^{28}$ In November 451, the council convened. It proved momentous. The assembled bishops invalidated Ephesus II, deposed both Dioscorus and Eutyches, ${ }^{29}$ and Leo's own Christological statement, the Tomus ad Flavianum (ep. 28), was accepted as orthodox and incorporated into the council's definitio fidei. ${ }^{30}$ From Rome's perspective, the council had settled the issue. As Leo stated to the eastern bishops, the religio Christiana was Chalcedonian. Even the smallest modification to the decisions made at the council undermined the faith. And the issue was not only theological. The council's ratification of Leo's Tomus-the first (and only) important papal intervention in the various late antique theological controversies over the Trinity and Christology-meant that any alteration of Chalcedon also threatened Leo's own authority, and by extension, that of the bishops of Rome.

\section{Heresiological Comparison in Context}

Unfortunately for Leo, many Christians, especially in the eastern half of the empire, were more worried about the orthodoxy of Chalcedon than preserving Rome's reputation. Opponents of the council, most of whom were relative moderates and did not support Eutyches or adhere to his Christology, nevertheless regarded Chalcedon as "at best an unnecessary innovation upon Nicaea and at worst as doctrinally unsound, fearing that both Leo's Tome and the convoluted Definition of Faith came dangerously close to a 'Nestorian' division of Christ into two persons," in the words of Michael Gaddis (2005, 51; see also Meyendorff 1989, 187). To defend the orthodoxy of Chalcedon and his own legacy (and that of Rome), Leo turned to heresiology.

Heresiology, according to J. Rebecca Lyman, was "the combative theological genre for asserting true Christian doctrine through hostile definition and ecclesiastical exclusion" (Lyman 2007, 296, see also 1997, 450; Cameron 1994; Cameron 2003; Berzon 2016). ${ }^{31}$ The genre evolved gradually over the course of the first three Christian centuries in the context of Greco-Roman classical rhetoric, invective, philosophy, ethnography, and historiography. ${ }^{32}$ At its core was polemical comparison, which was employed in the first instance to generate and reinforce a coherent Christian identity by contrasting this identity with a stereotyped 'other,' typically 'the Jews.' Although expedient for distinguishing Christian from non-Christian (or more accurately, creating these categories in the first place), late antique authors like Leo more commonly employed heresiology to delimit their own positions, invariably identified as orthodox, from all other understandings of the faith, which were described as heretical. But because 'heresy' often looked a lot like 'orthodoxy' and 'heretics' considered themselves and their beliefs 'orthodox,' the heresiologist, like the ancient ethnographer, sought to inventory the multiplicity of Christian belief and practice. This knowledge was then organized into cat-

28 On Pulcheria's role, see Schwartz (1927); Holum (1982, 208-16); Chew (2006, 225-27); Wessel (2008, 270-71).

29 On the transmission and translation of the Acta of Chalcedon, see Schwartz (1936, 256-75).

30 On the language and theological background of the Chalcedonian symbol, see Grillmeier (1951); Uthemann (2007, 488-92). On the reception of the definitio fidei and in particular of Leo's Tomus, see De Halleux (1976b); De Halleux (1976a); Uthemann (2001); Price and Gaddis (2005, 68-75).

31 On polemic in general, see Steckel (2018).

32 Heresiology also had a precedent in late classical Judaism. See, for example, Iricinschi/Zellentin (2008, 1316 with numerous refs); see also the interesting discussion of Christianity as a Jewish heresy in Rabbinic literature in Boyarin/Burrus (2005, 436-39). On the Christianization of ethnography, in addition to Berzon, see Inglebert (2001, 109-92) and on heresiology and Christian historiography, Inglebert (2001, 393-461). On the two principal forms of late antique comparative polemic considered here, that is the rhetorical demarcation of Christianity and the delimitation of authentic and inauthentic versions of the faith, see Brauner/Steckel (2020, 46-47). 
egories, which could be further historicized, classified, compared, and ultimately, controlled (Berzon 2016, passim, but esp. 5-22, 73-93). This type of knowledge creation is intrinsically polemical; it described 'heresy' in its relationship to 'truth' and/or compared it with analogous forms of 'untruth.' In short, neither heresy nor orthodoxy were lived historical phenomena; they were situational and relational discursive constructs that existed only in relationship with each other. Christian heresiology inscribed the border between these constructs and the heresiologists acted as the "inspectors of religious customs" in the memorable phrase of Daniel Boyarin, policing the frontier between (their understanding of) authentic and inauthentic Christianity (Boyarin 2007, 2-3).

Importantly and like most late antique Christian heresiologists, Leo understood orthodoxy and heresy genealogically. ${ }^{33}$ The former was the unchanging unitary truth of God exemplified in the original teachings of Jesus, which had been transmitted to his disciples, apostles, and was ultimately safeguarded by the bishops of Leo's own day (especially himself). Heresy, in contrast, was a later, derivative, and fraudulent departure from this original orthodoxy, inspired by the devil but produced by humans and likewise transmitted from generation to generation down to the present (Pourkier 1992, 56-59). Thus orthodoxy, or rather the process by which orthodoxy was invented, was a matter of developing a convincing narrative to explain and justify beliefs and practices in the present by locating their origins in the apostolic past; heresy, conversely, represented beliefs that had been successfully dislocated from an apostolic origin (Boyarin 2001, 427). This historical understanding of error encouraged the development of complex genealogical taxonomies to classify heresies, which allowed them to be understood in relation to each other and through their supposed affiliation with their historical antecedents. ${ }^{34}$ If a potentially suspicious teaching or belief could be demonstrated to have connections with, or be comparable to, a heretical predecessor, it was more easily exposed and refuted.

Labelling was a crucial part of this classificatory endeavour. Naming reified abstract assemblages of ideas or people into a bounded, coherent, heretical group with an associative identity and history, shared customs, and doctrines (Berzon 2016, 77-79). Heresies were typically named after their (supposed) founders. This was a common practice as early as the second, third, and fourth centuries amongst Christian heresiologists such as Justin Martyr, Irenaeus, Tertullian, Eusebius, and Epiphanius of Salamis, who transformed individual thinkers into heresiarchs by semantically shifting their names into abstract nouns and/or by rendering them into adjectival forms to describe their supporters. For instance, Tertullian described the partisans of the dualist first/second-century theologians Marcion of Sinope and Valentinus as 'Marcionites' (Marcionitae) and 'Valentinians' (Valentiniani). ${ }^{35}$ The followers of the Persian

33 Christian genealogies of error were influenced by doxography, a neologism coined in the nineteenth century to describe the categorization by Greek philosophers and historiographers of thinkers into discreet groups and traditions based on their beliefs, practices, and/or pedigree. The Greco-Roman physician Galen, for example, discussed various philosophical schools of thought or 'sects' (heiresis), especially the Platonic, Aristotelian, Epicurean, and Stoic 'schools,' ascribed to each of them an established system of beliefs and criticized people for adopting this or that sect without closely examining its doctrines (doxai). See, for example, Runia (1999) and van der Eijk (1999). On genealogies of error in Christian writing, see, for instance, Flower (2011).

34 An overview of this type of polemical comparison can be found in Brauner (2020).

35 "Marcionitae," adj., Marcionensis, -e, for the followers of Marcion: e.g., Tertullian, Adv. Marc., eds. Alexander Roberts and James Donaldson, 1.8, 1.19, 1.25, 1.27, etc. The title of Tertullian's work against Valentinus is Adversus Valentinianos - 'Against the Valentinians.' See also Tertullian, De Praesc. Haer., eds. Alexander Roberts and James Donaldson, 30-44; in Greek, see, for instance, Hippolytus, Ref. Omn. Haer., 7.30; 31; 37; Eusebius, Hist. eccl., 4.11; 5.13; 6.18; Epiphanius, Pan., 42-44. Similar processes still commonly take place in modern political discourse. 
mystic Mani ( $d$. 274) were routinely called 'Manichaeans' (Manichaei) in Christian polemical texts even though 'Manichaeans' themselves only rarely used this term. ${ }^{36}$ Perhaps the most famous and powerful instance of this process took place during the Trinitarian Controversy of the fourth century, when polemicists such as Gregory of Nazianzus and Athanasius applied

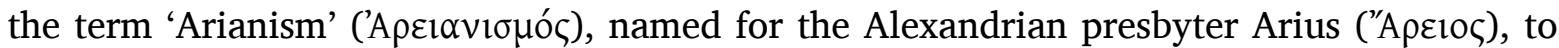
a myriad of contradictory theological positions whose only commonality was antagonism towards the Council of Nicaea. ${ }^{37}$ The act of naming connected all of these positions to Arius and through Arius, to a succession of previous heresiarchs. Gradually, the names of heresiarchs and the sects they had purportedly founded became epithets that acted as a shorthand for a constellation of (bad) ideas and beliefs-what a recent study has called the "polemic of individualized appellation" (Robertson 2018). By the fifth and certainly by the sixth century, for instance, 'Manichaean' had little to do with the reality of the Manichaean religion and instead was being used principally as a term of abuse (Cohen 2015, 214-21). Labelling heresies after heresiarchs also denied the name 'Christian' to theological opponents. 'Christians' adhered to the life-giving teachings, death, and resurrection of Christ; 'Valentinians,' 'Marcionites,' 'Arians,' and 'Manichaeans' were only parodies of the true faith, who followed the recent ramblings of mere men. "The act of 'interpellating' late antique individuals with comparable religious practices and ideas within a heresiological context," according to Eduard Iricinschi and Holder Zellentin, "transforms them into the 'other' and, at the same time, identifies them as "heretics" " $(2008,20)$.

While traditional heresiology formed the general background of Leo's polemic against Eutyches, the immediate context was the first phase of the Christological Controversy, which culminated in the Council of Ephesus I in 431. Before and after the council, both Cyril and Nestorius had mobilized the techniques of heresiological comparison to associate each other with previously condemned heresiarchs. For instance, writing to the bishop of Rome, Celestine (422-432), Nestorius accused "certain clerics amongst us," a thinly veiled reference to Cyril, of having taken up a heresy (the Latin translation of this letter uses the word aegritudo or 'disease') with "affinities to the putrid [illness] of Apollinaris and Arius (ACO 1.2, 12-14)."38 Nestorius also composed a number of other letters and polemical works which made the same allegations, for example in his second letter to Cyril (ACO 1.1, 29-30), and especially the Book of Heraclides written after his defeat and exile (Chadwick 1954, 156-57). Nestorius even accused Cyril of having been 'led astray by those condemned by the Holy Synod as Manichaean sympathizers of the clerics who perhaps share your opinions." 39 These comparisons appear to have stung Cyril, who complained that he was routinely defamed as having been influenced

36 On the positive and negative associations with the nomen Manichaeorum, see Lim (2008). On the transformation of 'Manichaean' into a term of abuse in late antique Roman polemical texts, see Cohen (2015).

37 Lyman (1993, 56-58); Gwynn (2010, 231-33); Gwynn (2007, 13-48); Williams (2017, passim, but esp. 112).

38 "est enim aegritudo non parva, sed adfinis putredini Apollinaris et Arrii [...]" See also his second letter, which makes a similar claim, (ACO 1.2, 14-15).

39 The accusation of Arianism and Apollinarianism remained a constant in 'Nestorian' (i.e., Syriac) Christianity's criticisms of both Monophysitism, and later, Chalcedonianism. See, for example, the collection of later Syriac polemical material collected in Abramowski and Goodman (1972, passim, but esp. 4 (Cyrillians accused of Arianism and Apollinarianism), 19-20 ("one nature" theology as Apollinarian), 38 ("the heretics" who adhere to "one hypostasis" compared to Mani, Marcion, Arius, Eunomius, Apollinaris, Paul of Samosata, Eutyches, Cyril and others), 76 (Cyril's First Anathama regarded as Apollinarian), 82 (the wording of Cyril's Tenth Anathema compared to that of Arius), 107-10 (a condemnation of Apollinaris' "one nature" theology), 16 (another condemnation of Apollinaris and "the Egyptian", presumably Cyril), 20-21 (various anathamas against Arians, Patripassionists, etc)). 
by Apollinaris and Arius (Cyril, ep. 33.9). ${ }^{40}$ Several of these comparisons would be taken up by later opponents of Eutyches and Dioscorus including Flavian and Leo.

Unsurprisingly, Cyril also employed heresiological comparison, using genealogies of error to link Nestorius to Paul of Samosata and Arius. ${ }^{41}$ By accusing Nestorius of 'Arianism' in particular, Cyril declared his own innocence of the same charge while simultaneously impugning Nestorius and his teachings. Moreover, it allowed Cyril to present himself as a latter-day Athanasius, the bishop of Alexandria who had opposed Arius and defended Nicaea in the fourth century. As Athanasius had done, Cyril was now doing. The link between the two men was thus both theological and institutional, a link that Dioscorus would also later claim and which Leo would attempt to sever. In contrast, Cyril described Nestorius as the most recent example of a questionable theological school, which Cyril and Dioscorus would come to label as 'Nestorian. ${ }^{42}$ As used by Egyptian controversialists and later by Eutyches and Leo, the adjective 'Nestorian' became a strawman - an epithet suggesting extreme dyophysite positions, which had little in common with Nestorius' Christology or those of his supposed antecedents (Price 2009, 25). In a similar example from the later fifth century, the Chalcedonian party in Alexandria was sometimes contemptuously referred to by the supporters of Dioscorus, Timothy Aeluros, and Peter Mongus as the 'Proterians,' a reference to the murdered bishop with which this essay began (Haas 1993, 306).

\section{Association and Disassociation: Leo's Heresiological Polemic at Work}

As should be clear from this brief overview, polemical comparison and classification were central features of the heresiological rhetoric employed during initial phases of the Christological Controversy. And Leo used these same techniques in his letters and tractates to associate Eutyches' teachings with previously condemned errors, including that of Nestorius, to cast Eutyches as a heresiarch of his own demonically inspired sect of Eutychians, to disassociate that sect from the orthodox tradition, and to identify that tradition as uniquely corresponding to that which was preached by the bishop of Rome. He did this in part through the construction of a double genealogy of apostolic orthodoxy on the one hand, and demonic error on the other. Eutyches had, according to Leo, failed to properly understand Christ's nature and his place in the salvation of humanity. This error had one of two origins (and was possibly a conflation of both): Mani and Marcion, whose docetic Christology denied the truth of the Incarnation, or Apollinaris, who taught that Christ's divine nature subsumed his human nature and suffered on the cross-the heresy of Patripassianism. Eutyches had, according to a sermon preached by Leo in February, 454, seized upon an "old madness (uetera insania) in the spirit of an already refuted and condemned error," when he denied the twofold nature of Christ. ${ }^{43}$ Elsewhere, Leo described Eutyches as one who "wallowed in the impious errors of the ancient heretics (ueterum haereticorum) [and] had chosen the third dogma of Apollinaris," that

40 He also explicitly denies his connection to the teachings of Apollinaris' various other letters: see, for example, Cyril, e 30.2, 40.23-40.24, 44.3, 45.5, 100.2-3.

41 Accusations of Arianism, see, for instance, Cyril ep. 23.

42 On the construction of the Antiochene 'school' associated with Nestorius, see esp. Sillett (1999, 41-56).

43 This is a gross oversimplification. In his fight against Arius, Apollinaris had claimed that Christ did not have a human soul. His teachings were condemned at the Council of Constantinople in 381 . The critique was useful, however, as Athanasius and especially Cyril may have been influenced by Apollinaris' Christology. See Galtier (1956); Young (1971, 105-7). 
is, he denied the reality of Christ's humanity (ep. 124, ACO 2.4, 159-163 at 159-60). ${ }^{44}$ Even if "that heretic" Eutyches could somehow be convinced to recant the views of Apollinaris, he would still cross over into docetism like "the insanity of Mani and Marcion" (ep. 124, ACO $2.4,159-163$ at 160). And because heresy was ultimately demonic, Dioscorus became "an Egyptian plunderer" who preached the devil's errors; ${ }^{45}$ Dioscorus and the "insane" Eutyches were tools of Satan and "the soldiers of the Antichrist (milites antichristi)." "It is the impious Eutyches," Leo complained to Julian of Cos, "who wages a war against the evangelical and apostolic teachings, a war which is bound to involve him and his associates in ruin" (ep. 109, ACO 2.4, 137-138; trans. (with modifications), Hunt (1957), 194-97). Leo's own Christology accepted at Chalcedon, in contrast, contained nothing innovative; it was simply a recapitulation of Nicaea (ep. 162, ACO 2.4, 105-107). Here, Leo was claiming to stand in continuity with the Fathers of the Church over and against the divisive ideas taught by opponents of Chalcedon like Eutyches, who had merely revived previously condemned ancient heresies.

The polemical impact of these assertions is plain enough: Eutyches' theology was derived from some of Christianity's most infamous heretics (if not from the devil himself) and therefore must be opposed and excluded. But the nature of heresiology meant that the accusation here goes further than simple comparison. Eutyches' error was not merely like these earlier heresies; because heresy was widely understood genealogically, for all intents and purposes, Eutyches was these heresiarchs, or at least equivalent to them (ep. 165, ACO 2.4, 113-119). ${ }^{46}$ This was the principle of apostolic succession applied to heresy; whereas Leo derived his legitimacy as bishop of Rome from his supposed historical continuity with the apostles Peter and Paul, and more generally the tradition associated with the Fathers and the Councils, heretics like Eutyches similarly received a sort of inverse, demonic 'legitimacy' from their perceived connection to earlier heresiarchs. Eutyches was thus the "most recent champion (redivivus assertor) of an already condemned error," 47 or one who "followed an already condemned heresy." ${ }^{48}$ Eutyches had "obviously veered over into the madness of Valentinus and Mani." He and his supporters only "pretend to hold to the faith of the Council of Nicaea" but in reality, they had rejected it (ep. 60, ACO 2.4, 29). ${ }^{49}$ Of course, the arguments over Christology had largely arisen after 325. But the genealogical nature of heresy and orthodoxy meant that, at least according to Leo, Eutyches' arguments had been refuted and condemned more than

44 June 15, 453, to the monks of Palestine. "Eutyches quoque eodem percellatur anathemate, qui per impios veterum haereticorum volutatus errores tertium Apollinaris dogma delegit [Also Eutyches, who, having chosen the third dogma of Apollinaris wallows in the wicked errors of ancient heretics, must be struck down by the same anathema]." Here "eodem anathemate" refers to Nestorius-that is, Eutyches must be condemned by the same anathema as Nestorius. See August 17, 458 to Emperor Leo, ep. 165 (ACO 2.4, 113-119). Much of this latter epistle was almost directly taken from the former.

45 ep. 120 (ACO 2.4, 78-81). Note, however, that Silva-Tarouca $(1931,183)$ considers this letter spurious.

46 To Emperor Leo, 458. Leo compares Eutyches to Mani and Manichaeism in several additional letters, including ep. 59 (ACO 2.4, 34-37) to the people and clergy of Constantinople and to Julian of Cos, dated 452, ep. 109 (ACO 2.4, 137-138).

47 June 9, 451, to Emperor Marcian. ep. 83 (ACO 2.4, 42-43): “et olim damnati erroris rediuiuus assertor locum in Christi ecclesia non haberet [and the most recent champion of an already condemned heresy did not find a place in the church of Christ.]" In Christian sources such as Prudentius' Liber Cathemerinon 3.204, redivivus is used to describe Christ who 'lives again;' elsewhere, it means 'revived,' 'renewed' or 'renovated', especially when discussing buildings. In this passage, it has an almost temporal meaning, hence 'most recent,' although a more literal translation would be 'revived,' that is that Eutyches has 'revived' or renewed ancient heresy, or perhaps that Eutyches himself had been 'renewed' by his acquittal at Ephesus II. See Lewis and Short, redivius.

48 January 27, 452, to the Bishops of Gaul, ep. 102 (ACO 2.4, 53-55).

49 See also the so-called the "Address to Marcian" dated November, 451 (in two versions, Greek: ACO 2.1, 469-75; Latin: ACO 2.3.3, 114-119); trans. Price/Gaddis (2005, 3.111-20). 
fifty years before he had been born. Nicaea and Chalcedon were parallel in another important aspect: the former had condemned the arch-heretic Arius' Trinitarian heresy, the latter, Eutyches' Christological heresy (ep. 156, ACO 2.4, 101-104, quoted at 102). ${ }^{50}$

Within the internal logic of heresiological rhetoric, genealogies of error had another practical consequence. Having characterized the dispute as one between an eternal and unchanging orthodoxy ( = Leo, Nicaea, Chalcedon) and a revival of already condemned and demonically inspired errors from Christianity's past ( = Eutyches and his heretical antecedents), Leo could then marshal the writings of the Church Fathers-the victors over these previous hereticsand use them to refute Eutyches. Because the principal opposition to his own Christological position was in the east, where most church leaders viewed Cyril's authority as paramount and worried that Chalcedon left room open for a creeping revival of Nestorianism, Leo endeavoured to claim Eutyches' own Greek theological predecessors, especially the Alexandrians, Athanasius, Theophilus, and Cyril, and turn them against Eutyches and Dioscorus. ${ }^{51}$ This process was underway during the Council of Chalcedon itself. Having read Leo's Tomus into the record during the second session, the assembled bishops cried out, "This is the faith of the fathers! This is the faith of the apostles! [...] We orthodox believe accordingly. Anathema to him who does not believe accordingly! [Saint] Peter has uttered this through Leo. The apostles taught accordingly. Leo taught piously and truly. Cyril taught accordingly. Eternal is the memory of Cyril. Leo and Cyril taught the same. Leo and Cyril taught accordingly. Anathema to him who does not believe accordingly!"52 Of course, not everyone agreed. ${ }^{53}$ However by the end of the session, the bishops cried out for Dioscorus' exile, adding the classic heresiological quip, "whoever is in communion with Dioscorus is a Jew!" 54 During his trial, Dioscorus was also accused of sharing Eutyches' heresy, and, in obvious attempt to discredit him, of having mistreated the relatives and associates of Cyril. ${ }^{55}$

In fact, while Dioscorus and Eutyches shared a deep hostility towards the teachings of Nestorius and his supporters, they had quite different Christologies. Dioscorus had even agreed to the condemnation of Eutyches at Chalcedon and declared his willingness to accept Flavian's "from two natures after the Incarnation"-the very formulation that was used to condemn

50 "in quo [sc. Nicaea] sancti et uenerabiles patres nostri contra Arrium congregate, non carnem domini, sed deitatem filii omousion patri esse firmarunt, in Calchedonensi autem concilio aduersum Eutychianam impietatem definitum est de substantia uirginis matris dominum Iesum Christum sumpsisse nostri corporis ueritatem [It was there [sc. Nicaea] our holy and venerable fathers, having gathered against Arius, affirmed that the divinity of the son, not the flesh of the Lord, was homoousios [the same substance or essence, Lat. consubstantialis] with the father. At the Council of Chalcedon, however, it was determined against the Eutychian impiety that the lord Jesus Christ took up the reality of our body from the substance of the virgin mother]."

51 Many assessments of Leo's Christology and the definitio fidei adopted at Chalcedon consider them to have departed significantly from Cyril's emphasis on the unity of Christ's human and divine natures. However, I am less interested in the theological nuances of the debate here. What is significant in the context of the present essay is that Leo's polemic appropriated Cyril and the other Alexandrian theologians in support of Chalcedon despite protestations from the council's opponents such as Dioscorus, who arguably had a far better claim to this legacy and who came much closer to upholding Cyril's Christology. On the Council's attempt to reconcile Cyril's Christology with Leo's, see Davis (2008, 50-51); de Urbina (1951). See also Loon (2009), who claims Cyril's Christology was essentially dyophysite. On the differences between Cyril and Leo, see Grillmeier (1975, 534-35). The Tomus was viewed by its critics as 'Nestorian.' See Green (2008, 227-30).

52 ACO 2.3.2, 15. trans. with modifications, Price/Gaddis (2005, 2.24-25). The reading of the Tomus was preceded by the Nicene Creed, Cyril's second letter to Nestorius and to John of Antioch, which were likewise greeted with similar acclamations by the assembled bishops.

53 For instance, the Illyrian and Palestinian bishops at Chalcedon. See ACO 2.3.2, 15-16.

54 ACO 2.3.2, 17: "Qui communicat Dioscoro Iudaeus est."

55 On this, see the discussion in Price/Gaddis (2005, 2.31). 
Eutyches at the Home Synod in $448 .{ }^{56}$ Despite this, Leo worked to associate Dioscorus with Eutyches, and to disassociate both from the patristic tradition, especially from Cyril. As Leo asserted to Paschasinus, who would serve as one of Rome's representatives at Chalcedon, Eutyches' abominable impiety had already been condemned and destroyed by the patres in their fight against earlier heretics (ep. 88, ACO 2.4, 46-47, at 46). ${ }^{57}$ To Emperor Theodosius II, Leo claimed that the defenders of the Catholic faith, writing in "both Greek and Latin," had produced works which can "amputate that error now emergent [ $s c$. that of Eutyches and Dioscorus], just as it destroyed the Nestorian heresy." Tellingly, the only church father named is Cyril (ep. 69, ACO 2.4, 30-31). ${ }^{58}$ Writing to Pulcheria after Theodosius' death, Leo declared that Eutyches had already been "defeated in the persons who were his sources [sc. Cyril]. If he had any soundness of mind, it could easily have restrained him from attempting to stir up the already buried ashes into a fresh fire and thus passing over into the society of those whose example he followed" (ep. 79, ACO 2.4, 37-38; trans. Hunt (1957), 144-47). ${ }^{59}$ Eutyches was a follower (sectator) of an "already condemned error," ${ }^{60}$ and his Christology had already been uncovered and condemned by the very authorities he claimed to uphold-namely Cyril and Athanasius. ${ }^{61}$ Leo claimed that he had in fact taught nothing new; it was Dioscorus who had been unwilling to follow the faith of the Fathers. Had he consulted the "works of Athanasius of blessed memory, and the discourses of Theophilus and Cyril," Dioscorus would have found that they had already contradicted and condemned the teachings of Eutyches (ep. 129, ACO 2.4, 84-86). Writing to Emperor Marcian in Spring 454, Leo likewise asserted that those Alexandrians hostile to Chalcedon should "read what blessed Athanasius, what Theophilus [Cyril's predecessor as bishop of Alexandria], what Cyril, what even other Eastern teachers thought about the Lord's Incarnation" (ep. 130, ACO 2.4, 83-84; trans. Hunt (1957), 218-20). Here, Leo implies that Dioscorus and his supporters had not merely separated themselves from the true faith, which had been passed down to the present through the principal of apostolic succession; they had also separated themselves from the local orthodox traditions of Alexandria itself by rebelling against the very tradition taught by that venerable city's most prominent bishops. ${ }^{62}$

To buttress his argument, Leo circulated select passages from largely Greek patristic sources. ${ }^{63}$ Writing to Emperor Leo near the end of his pontificate, Leo appended a Latin (!)

56 It was Dioscorus' willingness to accept this formula that eventually led the council to reject it, replacing it with a stronger two-nature formula that made future reconciliation with the Egyptian Church almost impossible; as noted by Price/Gaddis (2005, 1.194, n. 209).

57 June 451 (i.e., before Chalcedon) to Paschasinus, Bishop of Lilybæum: "abominanda ergo est in Eutyche impietas, quae olim a patribus praecedentibus haereticis damnata atque destructa est [Therefore, the impiety, which was damned and destroyed by the Fathers in earlier heretics, must also be abhorred in Eutyches]." On the Fathers and their authority in Leo's thought, see Casula (2002, 76-77).

58 July 16, 450 to Theodosius II. See Leo's letter to Pulcheria on the same day with similar content, ep. 70 (ACO 2.4, 29-30).

$59 \quad$ April 13, 451.

60 ep. 102 (ACO 2.4, 53-55, quoted at 54): "Eutyches damnati olim sectator erroris [...] [Eutyches, the follower of an already condemned error]."

61 ep. 109 (ACO 2.4, 137-138). In a letter to the bishops of Gaul, Leo contrasted the supposed suffering of Alexandria under the tyrannical rule of Dioscorus, who had rightly been condemned and deposed at Chalcedon, with the city's glorious past. The see had been founded by S. Mark, "a discipulus of the most blessed Apostle Peter, in all things in certain agreement with the instruction of his teacher." Alexandria's more recent bishops, Leo names Athanasius, Theophilus, and Cyril, had likewise upheld orthodox beliefs. See ep. 102 (ACO 2.4, 53-55, at 54).

62 I thank Richard Flower for this observation.

63 Leo, who does not appear to have known Greek, depended on his trusted associates such as Marius Mercator, John Cassian, and especially Julian of Cos as translators. Julian was responsible for the Greek translation 
florilegium, which included works by Athanasius (a Latin translation of the ep. 59 to Epictetus, which, two decades earlier, had been used by Cyril to condemn Nestorius and Ephesus I), John Chrysostom (the Homilia de cruce et latrone and the Homilia de ascensione Domini), as well other texts by Theophilus of Alexandria, Gregory of Nyssa, Basil the Great, and a long excerpt from Cyril of Alexandria's letter against Nestorius. ${ }^{64}$ To Julian of Cos, Leo dispatched copies of Athanasius' letter to Epictetus, noting that the bishop of Alexandria, who had died in 373that is 58 years before Ephesus I and 78 years before Chalcedon-had "already beat down both Nestorius and Eutyches in the persons of the heretics of his own age." Therefore, Leo continued, "Let the followers of Eutyches or Dioscorus, who claim that our teachings depart from the doctrine and thinking of the Fathers, dare to accuse this man of such great authority [sc. Athanasius] of either ignorance or depravity" (ep. 109, ACO 2.4, 137-138; trans. Hunt (1957), 194-97).

This last letter to Julian points to another aspect of Leo's polemic. Especially in correspondence with eastern bishops and members of the imperial family, Leo described Nestorius and Eutyches as two extremes of the same error-a paradoxical dyad of Christological heresy. That this odd couple could in any way be linked at first seems strange. One recent scholar has claimed that Leo "thought Nestorianism still posed a threat" and that, after 449, Leo was preoccupied with a ten-year "joint offensive against Nestorius and Eutyches" (Green 2008, 202-3). This interpretation ignores the rhetorical context of the letters and tractates from which this "joint offensive" has been reconstructed. By describing Eutyches and Nestorius as the antipodal limits of the same heresy, Leo effectively tied Eutyches' supporters to the very heresy they claimed to oppose. The impietas Nestoriana and the Eutychis error were, as Leo explained to Pulcheria in the spring of 451, a gemina impietas, a twin or double impiety. The devil (subdolus hostes) had first used Nestorius and then Eutyches to attack the vulnerable church. But the Catholic faith ultimately emerged victorious in what Leo termed an agon virtutum, a struggle or contest of strength, thanks in part to the efforts of the empress (ep. 79, ACO 2.4, 37-38). ${ }^{65}$

In letter after letter, Leo makes the same point: if one heresiarch was worthy of condemnation, so too was the other. Their errors were different on the surface, to be sure, but they shared the "same spirit of falsity (spiritus falsitatis)," and therefore the catholica fides condemned both (ep. 75, ACO 2.4, 33). Just as Nestorius had to be opposed for overemphasizing Christ's humanity, so too must the supporters of Eutyches, because they denied "the reality of our flesh in the Lord Jesus Christ (ep. 50, ACO 2.4, 21-22)."66 Although by different paths, both Nestorius and now Eutyches deviate from the Catholic faith and both "drink from filthy reservoirs of diabolical falsehood rather than the pure spring of true light" (ep. 90, ACO 2.4,

of the Tomus - a tricky job considering the complexity of the theological vocabulary. Leo's commission to Julian for the translation of the Tomus can be found ep. 131 (ACO II.4, p. 87). That the florilegia Leo appended to the letters under consideration here were Latin translation of the Greek patres presumably reflects the fact that this was what was available and intelligible for the bishop of Rome. One wonders how a hodgepodge of snippets drawn from Greek sources translated into Latin would have been received by a Greek-speaking audience.

64 Appended to ep. 165: "Testimonia excerpta pro re supra scripta de libris catholicorum Patrum a Leone papa collecta Leonique imperatori directa" (ACO 2.4 119-131).

65 On Pulcheria's role, especially as it pertained the Theotokos controversy and the condemnation of Nestorius, see Cooper (2004); Chew (2006).

66 To the clergy, nobility and people of Constantinople, "nos enim sicut Nestorium in sua peruersitate anathamatizauimus, ita eos qui ueritatem carnis nostrae in domino Iesu Christo denegant, pari execratione damnamus" [Just as we have anathematized Nestorius in his perversity, so too we condemn with an equal curse those [sc. the supporters of Eutyches] who deny the truth of our flesh in the Lord Jesus Christ]. 
p. 48). ${ }^{67}$ Nestorius and Eutyches, together with his supporters, pose a dangerous challenge to orthodoxy (ep. 85, ACO 2.4, 44-45, quoted at 44). "For just as the Catholic Faith," Leo blustered, "condemns Nestorius, who dared to maintain two persons in our one Lord Jesus Christ, so does it also condemn Eutyches and Dioscorus who deny that the true human flesh was assumed in the Virgin Mother's womb by the only-begotten Word of God" (ep. 123, ACO $2.4,77) .^{68}$

This argument tarred Eutyches with the heresy of Nestorius. But Leo also recognized that a condemnation of Eutyches without a corresponding condemnation of Nestorius would have been read by many, especially those who were disposed to support a strong anti-Nestorian line, as a tacit approval of the latter's teachings. ${ }^{69}$ This was particularly important during the spring and summer of 451 in the leadup to Chalcedon, when Leo actively campaigned to have his Tomus accepted by eastern bishops. Written two years earlier, the Tomus had been principally concerned to counter Eutyches. On the eve of Chalcedon, it had to retrospectively be made to oppose Nestorius as well if it had any hope of gaining general acceptance in the east. To accomplish this, Leo circulated the Tomus together with a request that recipients approve the text and consent to the damnatio of both Eutyches and Nestorius. ${ }^{70}$ Reading the Tomus in the context of this dual condemnation moderated Leo's own Christological position and insulated him from accusations that he was in some sense 'Nestorian.' It also positioned the Tomus as an acceptable third option, which opposed the extremes of Eutyches and Nestorius. This approach had some success. Writing to Patriarch of Constantinople Anatolius-the man who had replaced Flavian with the support of Dioscorus and thus not a natural ally-Leo states, "since you yourself thought it right to inform [us] that all the eastern bishops (omnes orientales sacerdotes) have subscribed in support of the Catholic faith [here, a reference to Leo's Tomus] and in the damnation of Eutyches and Nestorius, we believe the work which is to be taken up at the council will proceed without any troubles of controversies" (ep. 91, ACO 2.4, 49). After the council had taken place, Leo continued to stress the point. If the two men were contrary manifestations of the same error, then supporting either one was little different than supporting the other: they were two contrary iterations of the same misunderstanding of the Incarnation (Tr. 28, CCSL 138, 139-145). ${ }^{71}$ Writing to the bishops assembled at Chalcedon in March 453, Leo asserted that both Eutyches/Dioscorus and Nestorius had arrogantly refused

67 To Emperor Marcian: "Catholica fides [...] a cuius integritate et Nestorius antea, et nunc Eutyches diuersis quidem callibus sed impietate non inpari deuiarunt [...] contra sincerum veri luminis fontem de caenosis lacubus diabolicę falsitatis hauserunt" [Both Nestorius previously and now Eutyches deviate from the integrity of [the Catholic faith] by different but no less impious paths [...] they drink from filthy reservoirs of diabolical falsehood rather than the pure spring of true light]. Note that ACO 2.4, p. 48 has a typo on line 17, diuersuis, which is correctly rendered in the PL as diuersis.

68 June 15, 453 to Aelia Eudocia, On Aelia Eudocia, see Holum (1982, chap. IV).

69 As Leo states in his letter to the monks of Palestine, ep. 129 (ACO 2.4, 84-86). A malicious mistranslation of the Tomus had been circulating that emphasized Leo's supposed Nestorian leanings leading some to accuse the Bishop of Rome of Nestorianism. Also noted by Green $(2008,208)$.

70 Leo's earlier, though related, strategy was to demand that his own Tomus be read alongside certain letters of Cyril. For example, in his letter to Pulcheria of July 450, Leo asks the empress to ensure Anatolius of Alexandria read "a letter from Cyril of blessed memory" as well as "my letter to bishop Flavian of blessed memory [the Tomus]." ep. 70 (ACO 2.4, 29-30). He makes a similar request in his letter of the same day to Theodosius II, ep. 69 (ACO 2.4, 30-31).

71 Here, Leo suggests that almost all errors stem from a misunderstanding of the incarnation, and thus all these errors are essentially the same. "Thus, in the many-faceted variations of a single doctrine, not only the nature of the flesh and of the soul, but the very essence of the Word has been wiped out." 
correction and had chosen instead to undermine the unity of the church. Thus, anyone who agreed with their teachings was anathema (ep. 114, ACO 2.4, 70-71). ${ }^{72}$

Not only were Eutyches' teachings the recycled detritus of the Marcionites, the Manichaeans, and the Apollinarians, and paradoxically linked with those of his theological nemesis, Nestorius. As this last letter to the bishops at Chalcedon suggests, Leo also came to describe Eutyches as the founder of a heretical sect complete with radical followers. This occurred gradually. Recall that Leo had exchanged letters with Eutyches in the second half of 448 and Leo had referred to the monk as "most beloved son" (dilectissimus filius), a standard subscriptio in a papal letter, but one that nonetheless indicates that Leo was not initially ill-disposed towards Eutyches. Even after receiving Flavian's reports, Leo had, at least to easterners, emphasized Eutyches' naiveté rather than malevolence. This changed following the receipt of Flavian's letters detailing Eutyches' condemnation and especially after Ephesus II. But by the summer of 451, Leo was routinely describing Eutyches as the head of a movement, complete with partisans (participes) and associates (consortes)" (ep. 85, ACO 2.4, 44-45, quoted at 44). In a letter to Maximus, bishop of Antioch, Leo explained the Christological Controversy as a three-way battle between the discipuli of Eutyches, the sectatores of Nestorius, and the Catholici, whose judgment condemns both heresies (ep. 119, ACO 2.4, 72-75, quoted at 73). ${ }^{73}$ In 452 , Leo portrayed anti-Chalcedonian violence in Palestine as a war waged by "the wicked Eutyches" through "the madness of his deceivers," although Leo was confident that "Eutyches and his allies (socii)" would eventually be defeated (ep. 109, ACO 2.4, 137-138 quoted at 137).

As the controversy progressed, Leo's polemic became increasingly abstracted and depersonalized. In Spring 451, Leo attacked the Eutychis error and impietas Nestoriana (ep. 79, ACO 2.4, 37-38). Here, Nestorius' name is used adjectivally (Nestoriana), generalizing it so as to suggest to the reader that the object of criticism is not the heresy of Nestorius, who in any case had died the previous year, but rather the kind of heresy taught by Nestorius: "the Nestorian impiety." Eutyches, on the other hand, is a proper name in the genitive case. He remains an individual, and the error is his own: "the error of Eutyches." "74 But by the end of that summer, this was beginning to change. In a letter written to Anatolius of Constantinople, Leo contrasted the Nestoriana impietas and Eutychiana insania, the "Eutychian insanity," using both Nestorius and Eutyches as adjectives (ep. 87, ACO 2.4, 45-46, quoted at 46). In the same way as earlier heresiologists had semantically transformed Marcion into Marcionites and Marcionism, and Arius into Arians and Arianism, Leo was beginning to describe Eutychians and Eutychianism. Following Chalcedon, Leo portrayed the council as orthodoxy's triumph over the "Eutychian impiety" (Eutychiana impietas) (ep. 156, ACO 2.4, 101-104, quoted at 102), or the defeat of both the "Nestorian impiety" and the "Eutychian madness" (Nestoriana impietas [...] Eutychiana uesania) (ep. 120, ACO 2.4, 78-81). Elsewhere, Leo attacked the Eutychian and Nestorian heresies (Eutychiana haeresis [...] Nestorianum execrabile dogma) (ep. 135, ACO

72 Many bishops had remained at Chalcedon because Leo refused to formally accept the council's acta because of the inclusion of canon 28, which had declared that 'New Rome,' that is Constantinople, should enjoy the same privileges as 'Old Rome.' Leo finally acknowledged Chalcedon in March 453, although he continued to reject canon 28 .

73 "nam licet Nestorium Eutychis discipuli detestentur et Eutychen anathematizent Nestorii sectatores, catholicorum tamen iudicio pars utraque damnatur et ambae simul haereses a corpore ecclesiae resecantur [For although the disciples of Eutyches detest Nestorius and the followers of Nestorius anathamatize Eutyches, each [of these errors] is nevertheless equally condemed in the judgement of the catholic faith and both heresies are together cut out from the body of the church]." Similarly, see ep. 120 (ACO 2.4, 78-81).

74 In Leo's writing, Eutyches is declined as follows: Nom: Eutyches; Gen: Eutychis; Dat: Eutychi; acc. Eutychen/m; abl: Eutyche. 
2.4, 88-89, quoted at 89) and claimed that violent protests by anti-Chalcedonians in Egypt had been incited by "factions of Eutychians" (Eutychianorum factiones) (ep. 131, ACO 2.4, 87). To Theoderet of Cyrus, Leo asserted that there should be no retreat in the fight "against the Nestorians or Eutychians" (contra Nestorianos aut Eutychianos), both of whom were the enemies of Christ who deserved to be struck down by anathema (ep. 120, ACO 2.4, 78-81). ${ }^{75}$ And, as we saw at the beginning of this essay, it was the Eutychianorum furor, the furor of the Eutychians, which resulted in the brutal murder of Proterius of Alexandria. Eutyches had become a heresiarch, the eponymous founder of the new heresy 'Eutychianism' whose adherents, the 'Eutychians,' posed an existential threat to the faith. But while 'Eutychianism' may have been new, its error was not. As I noted above, the genealogical understanding of heresy meant if one accepted Leo's claims, then the 'Eutychians' were functionally equivalent to the Nestorians, Valentinians, Apollinarians, and Manichaeans-a fact that would have important legal implications, which I will discuss in more detail below.

\section{Leo's Heresiological Comparisons: Effectiveness and Audience}

At the most basic level, Leo's equation of Eutyches with earlier heretics derives its rhetorical power by violating norms of comparison. Eutyches, an archimandrite in charge of a large monastic community at Constantinople with important connections to the imperial court and a leading opponent of heresy in his own right, was actually a heretic-either a Manichaean, an Apollinarian, or most surprisingly, equivalent to his nemesis Nestorius. This highlighted the (supposed) similarities between categories that ordinarily were understood as dissimilar and compared things that normally should be incomparable. In this way, "Eutyches is a Manichaean" is functionally similar to other common polemical comparisons highlighted by Christina Brauner, such as equating people to animals, boys to girls, adults to children, 'believers' to 'heathens,' or the 'Nazi comparison' (reductio ad Hitlerum) (Brauner 2020, 5). In the case of Eutyches, equating him with condemned heretics from Christianity's past implicated the monk in theological positions that had been dismissed by the church as indefensible, thus rendering Eutyches' own positions unacceptable.

While Leo's heresiological rhetoric was like other forms of polemical comparison, it differed in one important way. Comparison is often about similarity and difference (Brauner 2020, 38-40). But because the objects of heresiological comparison tend to be separated by significant periods of time-Mani, one of the supposed ancestors of Eutyches' error, died in $277 \mathrm{CE}$, while Apollinaris died in c. 377-the comparison tends to go only in one direction: from historical antecedent to the (supposed) contemporary manifestation of that antecedent. But since heresy was understood genealogically-a demonic inversion of the principle of apostolic succession-heresiological comparison strongly equates its comparata. Eutychianism was not like Manichaeanism and/or Apollinarianism; in an essential way, Eutychianism was Manichaeanism and/or Apollinarianism, or at least their theological progeny. The exception in the examples considered in this essay is Nestorius, a rough contemporary of Eutyches, who, as we have seen, was paired with the monk to create a paradoxical dyad of Christological er-

$75 \quad$ To Theoderet of Cyrus. "[...] exhortamur ut quia illic nonnullas Eutychiani ac Nestoriani erroris reliquias cognouimus remansisse, nunc etiam sedi apostolicae collabores [Because we have learned that some traces of the Eutychian and Nestorian error remain there [illic], we exhort that even now you [continue to] collaborate with the Apostolic See]." The illic presumably refers to Theoderet's see of Cyrus, although Leo may have intended something less specific, like 'the east' or perhaps the see of Antioch, to which Leo turns in the last part of this letter. 
ror. The function of this comparison, intended principally for an eastern audience, was to insulate Leo's own Christology from accusations of Nestorianism. I will return to this in more detail shortly.

The heresies Leo mobilized in order to denigrate opponents of Chalcedon were dictated by the context of the earlier phases of the Christological controversy and the internal logic of heresiological discourse. Eutyches' misunderstanding of the Incarnation (in Leo's view) mirrored that of Valentinian, Mani, and Apollinaris, thus they were naturally comparable. But the rhetorical impact of his comparata transcended historical precedent; they would have also evoked an emotional response amongst Leo's audience, who had been primed by decades of hostility to view Apollinarianism, Valentinian 'Gnosticism,' and especially Manichaeism as theologically and morally intolerable. ${ }^{76}$ This was an appeal to emotion, stereotype, disgust, and fear. The sexually depraved and perverse Manichaean, for instance, was a common trope used elsewhere in Leo's writing and beyond; although remaining as a subtext in Leo's letters, this image may well have been conjured in the imagination of his audience. ${ }^{77}$ Heresy was also conceptualized by late antique Christians as a highly contagious but difficult-to-detect sickness incubating in an unknowing host. ${ }^{78}$ Earlier in his pontificate, Leo had described Manichaeans using medical terms such as contamination, uncleanliness, infection, sickness, and disease. ${ }^{79}$ Now, it was Eutyches who was the Manichaean. The implication is clear-he, like other heretics, had to be cut off from the body of the Christian community before the infection could spread. And the reductive logic of heresiology meant that all opponents to his own Christology who emphasized the union of Christ's human and divine natures, including Dioscorus as well as later leaders such as Timothy Aelurus and Peter Mongus, could be characterized by Leo as "Eutychians" (Eutychiae, Eutychianistae, or Eutychiani), all of whom in fact rejected Eutyches' confused Christology ${ }^{80}$ Nevertheless, they were "the impious men of 'the Eutychian dogma" " (ep. 164, ACO 2.4, 110-112). ${ }^{81}$ And by 458, Egypt, which was then under the control of Timothy Aelurus, could be described by Leo as suffering under the "lamentable captivity" of the "disciples of Eutyches and Dioscorus" (ep. 162, ACO 2.4, 105-107).

Despite the apparent power of these kinds of accusations, it is unlikely that they would have been convincing to the supporters of Dioscorus and his successors. Calling Eutyches an Apollinarian and/or a Manichaean-or calling Dioscorus a Eutychian-is a very different proposition than engaging substantially with (or producing a detailed refutation of) a theological argument, something Leo does only rarely. Polemical comparisons of the kind employed by Leo-name-calling, genealogies of error, associations with the devil—would not have been effective in changing the minds of anyone who held the positions being critiqued. Stated differently, the people Leo labeled as heretics thought that it was Leo who was the heretic. It is

76 Leo himself had, in the decade before the Ephesus II, repeatedly condemned Manichaeism as much for its moral unacceptability as for its theological absurdity. For an overview with citations, see Cohen (2022, forthcoming).

77 On this aspect of polemical construction of self and other, see esp. Steckel $(2018,22)$.

78 Interesting to write this during the Covid-19 pandemic in the summer of 2020.

79 Disease, contagion, infection: tr. 16 (CCSL 138, 61-67), §5; tr. 24 (CCSL 138. 109-116), §4; tr. 34 (CCSL 138, 178-187), §4; tr. 42 (CCSL 138a, 238-250), §5. cf. ep. 7 (PL 54, p620-622), §1. Leo sometimes uses medical imagery in his sermons to describe salvation brought by faith in Christ (a "remediorum medicina" offered to humanity in this life). See, for example, tr. 9 (CCSL 138, 32-38), §1.

80 Interestingly, Acacius had denounced Peter Mongus as a "a Eutychian heretic," which suggests that this polemic had moved beyond Latin/papal literature and entered the mainstream of heresiological rhetoric. Acacius' accusation is preserved in Simplicius' (468-483) biography in the Liber Pontificalis: "Sub huius episcopatum uenit relatio de Grecia ab Acacio Constantinopolitano episcopo et adfirmauit Petrum, Alexandriae urbis, eutychianistam hereticum, facta petitione ab Acacio episcopo, cyrographo eius constructa." "[...] Eutychiani dogmatis impietatem [...]". 
possible, however, that Leo's polemic could have made an impact upon the many individuals who were not deeply implicated in either the pro- or anti-Chalcedonian camps. Comparisons to arch-heretics radically simplified complex theological positions into two camps, good vs. evil, truth vs. lies, which may well have sown seeds of doubt amongst marginal anti-Chalcedonians, who themselves were forced to defend themselves from these accusations. But the letters and tractates reviewed in this essay likely served primarily as insider literature, reinforcing the support of those already disposed to support Rome and limiting defections of those on the fence by placing alternatives beyond the boundaries of acceptable belief.

\section{Conclusions}

In a few short years, Leo transformed Eutyches from a beloved son and defender of orthodoxy against Nestorianism to a misguided elderly monk, to a heretic comparable with Nestorius himself, to the eponymous founder of a demonically inspired sect, which comprised everyone who disagreed with the bishop of Rome or who was unsure about the orthodoxy of Chalcedon. By the end of Leo's pontificate, Eutyches the man had become a 'hermeneutical Eutychian,' to borrow a phrase from Jeremy Cohen, who described the invention of the 'hermeneutical Jew' by Christian authors, an abstraction disconnected from the lives and beliefs of actual, living Jews, which served the exegetical and theological agendas of the authors who employed it. ${ }^{82}$ Leo's hermeneutical Eutychian was likewise a discursive construct intended to advance Leo's own theological agenda: the construction of an orthodox identity coterminous with adherence to Chalcedon. As we have seen, Leo's polemic was firmly rooted in the traditional heresiological writings of authors such as Irenaeus, Tertullian, and Athanasius, but especially the conflict between Cyril and Nestorius. Decades earlier, Cyril and his allies successfully elevated Nestorius into the pantheon of heresiarchs; 'Nestorianism' became a common term of abuse from the fifth century onwards, an abstraction to be derided and despised no less than 'Arianism.' Interestingly, the lingering association between Cyril and Apollinaris implied in Nestorius' own writings also continued to reverberate after the bishop of Alexandria's death. For instance, Flavian's letters to Leo at the end of 448 claimed that Eutyches was "reviving the ancient sect of the impious Valentinian and Apollinaris." 83 And Eutyches was convicted at the Home Synod of Apollinarianism. Tellingly, his own confessio fidei, which he sent to Leo, attempts to preempt these accusations by anathematizing "Apollinaris, Manes [sc. Mani], Valentinus, Nestorius" and "all heretics back to the time of Simon Magus." 84 These accusations and Eutyches' response to them almost certainly influenced Leo's own polemic against Eutyches and, subsequently, against the opponents of Chalcedon.

The invention of 'Eutychianism' was perhaps Leo's most enduring contribution to the defense of Chalcedon. And after the bishop's death in 461, Chalcedon's unpopularity amongst many in the east meant that Leo's successors had to remain on the offensive if they wished to preserve the council. Events culminated with the promulgation of the Henotikon (Edict of

82 See especially Cohen (1999, 2-3 and passim), but also Harkins (2005, 42 n.3).

83 Flavian, Relatio ad Papam Leonem de Damnatione Evtychis (ACO 2.2.1, 21-22). "[...] antiquam impii Valentini et Apollinaris reparans sectam". Similarly in his second letter to Rome, Alia epistola ad Papam Leonem de Evtychem (ACO 2.2.1, 23-24): "Necessarium ergo fuit ut animaduertentes laedi ueram religionem et renovari Apollinaris < et $>$ Valentini ab Eutychin nos non dissimularemus, sed manifestaremus eum reuelaremus ad cautelam populi."

84 Libellvs appellationis Eutychis ad Papam Leonem (ACO 2.2.1, 33-35). Eutyches' confession fidei, especially the reference to Simon Magus, suggests the influence of heresiological catalogues like Epiphanius' Panarion, which routinely cast Simon as the originator of the first Christian heresy. See, for example, Pan. 1.21. 
Union) in approximately 482 by Emperor Zeno. ${ }^{85}$ The Henotikon was a theological compromise authorized by the Patriarch of Constantinople Acacius intended to satisfy both Chalcedonians and anti-Chalcedonians in the east. While it explicitly condemned both Eutyches and Nestorius, the Henotikon sidestepped the complex theological issues of the debate altogether and instead emphasized the orthodoxy of Nicaea and of the Council of Constantinople (381). ${ }^{86}$ The bishops of Rome interpreted the Henotikon's failure to explicitly endorse Leo's Tomus as akin to an outright rejection of the cornerstone of Christological orthodoxy. ${ }^{87}$ This was a theological question. At issue were questions of salvation that were doubtlessly important to the protagonists discussed in this essay. But authority was also part of the equation. Leo's contribution to Chalcedon meant that none of his successors could assent to a theological formula that compromised Chalcedon. To accept the Henotikon would not only signal a willingness to consent to imperial interference in matters of church dogma and doctrine, but it would also imply that Leo's Christological theology was subject to revision. Ever since the time of the Henotikon's promulgation, Felix III, Simplicius, and especially Gelasius responded by taking a page from Leo's playbook: they collapsed any opposition to Chalcedon and all supporters of the Henotikon in the heretical category of 'Eutychian'-which in turn could be associated with condemned heretics from the past while firmly placing Leo and the bishops of Rome more generally within the long patristic tradition all the way back to Nicaea. According to Gelasius, for instance, Chalcedon and Leo's Tomus must be preserved. Everything else, including the Henotikon, was tantamount to "the Eutychian error" (ep. 27.3, ed. Thiel (1868), 422-435). Even the most modest compromise of Chalcedon was no different than the "Eutychian plague (Eutychiana pestis)" or the "insanity of Eutyches" (Eutychetis insania) and his followers (sectatores). ${ }^{88}$ The fact that the Henotikon specifically condemned Eutyches did not matter. As Gelasius understood it, it was simply impossible for anyone to, on the one hand, condemn Eutyches, while on the other, to remain in communion with people who were no better than Eutychians themselves (ep. 27.10, ed. Thiel (1868), 422-435). It was thus imperative to avoid communion with the Eutychian plague (pestis) and those who supported it (frag. 1, ed. Thiel (1868), 483-484). Also following Leo, Gelasius described Eutyches' error as a derivative mix of the errors of the Marcionites and the Manichaeans. In a letter to the bishops of Dardania, the Balkan province north of Macedonia and south of Moesia, Gelasius recapitulated the history of the Christological controversy, asserting Eutyches' "impious and wicked invention" was in fact "a mixture of Marcionism and Manichaeism" (ep. 7.2, ed. Thiel (1868), 335-336 = CA ep. 79, 218-223). ${ }^{89}$ But it was more than simply an amalgamation of already

85 The exact date of its promulgation is uncertain. See Blaudeau (2006, 203, n. 590). The Henotikon is preserved in three sources. In Greek: Evagrius, Hist. Eccl. 1.10 (ed. Whitby 2000, 147-49); Ps.-Zachariah Rhetor, Chronicle (ed. Greatrex 2011, 198-201). In Latin: Liberatus, Breviarium causae Nestorianorum et Eutychianorum (ACO 2.5, 98-141, at 127-29). Liberatus' text was likely composed sometime between 560566 and summarizes (from a Chalcedonian perspective) the Christological Controversy in the context of the Three Chapters controversy. For an excellent introduction to Liberatus and his Breviarium, see Zeitschrift für Antikes Christentum 14, which is entirely dedicated to the subject; in particular, Brennecke (2010, 74-95).

86 The background, theology, and reception of the Henotikon is discussed in Caspar (1930-1933, 2:10-81); Grillmeier (1986, 247-88). On the Henotikon and its significance for Christology after Chalcedon, see Brennecke (1997).

87 See, for example, Felix III's letter to Zeno sent in the wake of the promulgation of the Henotikon: ep. 1 (ed. Thiel (1868), 222-232). See Schwartz (1936, 266-67). According to Gelasius, the Henotikon had for all intents and purposes overturned or condemned the Council of Chalcedon.

88 E.g., Gelasius, ep. 18.2 (ed. Thiel (1868), 382-385 = Collectio Avellana (CA) ep. 101, ed. Günther (18951898), 464-468); ep. 26.1 (ed. Thiel (1868), 392-413 = CA ep. 95, 369-398). insania: ep. 26.6 (ed. Thiel (1868), 392-413 = CA ep. 95, 369-398).

89 " $[. .$.$] Eutyche quondam presbytero Constantinopolitano in blasphemias proruente, per quas diceret, unam$ tantummodo, id est solam Divinitatis, naturam sive substantiam in Domino Jesu Christo credere nos de- 
condemned errors from Christianity's past; in Gelasius' view, Eutychianism was a specifically Greek phenomenon. Heresies like that of Eutyches flourish apud Graecos, according to Gelasius; and Chalcedon was nothing less than the defeat of "the Greeks" by "the Apostolic See and by Saint Leo of blessed memory and by his successors as their written records, which we possess, demonstrates without ambiguity" (ep. 7.2-3, ed. Thiel (1868), 335-337 = CA ep. 79, 218-223). ${ }^{90}$

Crucially, heresiological labels could transcend the realm of discourse. Through the application of Roman law, heresiology produced the very objects it invented and described (Humfress 2007, 241-2). ${ }^{91}$ This can be seen in Title 5 of Book XVI of the Codex Theodosianus, De haereticis, which contains excerpts from fourth- and early fifth-century imperial pronouncements targeting a myriad of heretical sects. These laws ${ }^{92}$ adopt (and adapt) heresiological taxonomic logic: heterodox sects, imagined as coherent objects, are labeled as 'Arian,' 'Apollinarian,' 'Donatist,' etc., and are classified based on the nature and seriousness of their error (Flower 2013, 189-90). And as the Roman state became involved in regulating correct and incorrect belief, heresy was increasingly understood as a threat to the public order and imperial legitimacy. ${ }^{93}$ Heretics were, therefore, barred from assembling to pray anywhere on Roman territory (CTh 16.5.65 = CJ I.5.5, 428 CE). Several heresies, including Manichaeism, Arianism, and Apollinarianism, were seen as particularly dangerous and were therefore subject to especially harsh penalties, including infamia, which effectively revoked the benefits of Roman citizenship such as the right to pass down property as an inheritance and to testify in court. ${ }^{94}$ Thus, the successful application of any of these labels to a theological opponent could have dire legal consequences, effectively delegitimatizing their right to exist in an orthodox world.

In the wake of Chalcedon, the heresiological logic of Roman law was applied to those who continued to oppose the council. A pronouncement in the name of Valentinian and Marcian in 455 was promulgated against the followers of the "profane perversity of Eutyches," who opposed the faith established at Nicaea, supported as it was by Athanasius, Theophilus

bere, susceptae carnis veritate prorsus abolita. Quod utique impium prauumque commentum, Marcionistis Manichaeisque coniunctum, totum sine dubio salutis nostrae solueret sacramentum [... Eutyches, a certain presbyter from Constantinople, fell into blasphemies through which he taught that we ought to believe that there was only one nature or substance in the Lord Jesus Christ-that is, only the nature or substance of divinity, while the truth that Christ took up human flesh was completely abolished. Certainly, such an impious and wicked invention—a mixture of Marcionism and Manichaeism—without doubt destroys the sacrament of our salvation]."

90 "[...] ab apostolica sede et per beatae memoriae sanctum Leonem et per successores ejus certum est Graecos, fuisse convictos, sicut ipsorum chartis, quas apud nos habemus, sine ambiguitate monstratur [it is certain that Greeks were defeated by the Apostolic see and by Saint Leo of blessed memory and by his successors, as their written records, which we possess, demonstrates without ambiguity]." On the context of this letter to the Dardanian bishops, see Cohen (2019, 170-71 with refs.).

91 Although there were numerous forms of error, the Code considered them all part of a single criminally illicit category, sacrilega superstitio, which stood in opposition to vera religio (e.g., CTh 16.5.63).

92 The excerpted pronouncements preserved in the Theodosian Code are typically referred to as 'laws' in secondary literature, but this is not strictly accurate. They are in fact, with rare exceptions, letters addressed to imperial officials and should not be taken as representative of a coherent program of imperial legislation. I use the term 'law' in what follows with this caveat in mind. On this distinction, see Millar (2006, 7-8), noted in Flower (2013, 174, n.7).

93 The construction of heresy and heretics was, therefore, also a Roman imperial discourse. As Todd Berzon notes, "the heretics emerged as a legal category that reinforced the terms of orthodoxy as public, institutional, and imperial" (2017, 126-7).

94 For a complete list of heresies targeted by sentences of infamia and references to the relevant laws, see Humfress (2008, 137-8). Manicheans would eventually be subject to the death penalty. See CJ I.5.11 (487 or $510 \mathrm{CE}$ ) and CJ I.5.12 (527 CE). 
and Cyril, as well as the Councils of Constantinople, Ephesus (I) and "the venerable synod of Chalcedon," which "agrees entirely with the decisions of the previous councils of priests, neither adding nor subtracting anything from the creed ("sacrosancto symbolo") but condemning the deadly teachings of Eutyches." The law continues: "Let the followers of Eutyches know that they are Apollinarian heretics (haeretici apollinaristae). For Dioscorus and Eutyches sacrilegiously followed the criminal sect of Apollinaris." 95 This law perfectly reflects Leo's anti-Eutychian polemic: Chalcedon was orthodox and preserved the tradition of the church fathers-especially Athanasius and Cyril—as well as earlier ecumenical councils. Eutyches, on the other hand, was an Apollinarian heretic.

With the support of Roman law, Leo's invention of Eutychianism moved beyond polemic. As Leo had done, this law equated the supporters of Dioscorus and Eutyches with Apollinarians, which meant that "Eutychianism" was legally equivalent to Apollinarianism. ${ }^{96}$ The Eutychians were Apollinarians, "although different in name, they are yet joined in the wickedness of heresy; the name is dissimilar, but the sacrilege the same." "Thus Eutychians would be subject to same penalties and prohibitions as Apollinarians, including the sentence of infamia, the denial of the right of assembly and church construction, prohibition from imperial service, and a ban on the appointment of priests and bishops against the will of an orthodox (i.e. Chalcedonian) bishop. ${ }^{98}$ No "Eutychian or Apollinarian" would be permitted to call meetings or to discuss "their heretical error" and to profess "the wickedness of their criminal doctrine" in public or in private. ${ }^{99}$ Even the possession of Eutychian books was made a criminal act punishable by perpetual exile. ${ }^{100}$ The emperors also imposed an extremely harsh fine of ten pounds of gold on anyone who merely discussed the heresy (discendi studio audierint), even if it came from a desire to understand its teachings, and called for the death penalty (ultimo etiam supplicio coerceantur) for those who dare to actually teach it. ${ }^{101}$ Finally, all the books and pamphlets that "contain the accursed teachings of Eutyches, that is, of Apollinaris, shall be burned by fire, so that the very traces of this criminal wickedness may perish, consumed in the flames. For it is fitting that punishment of equal magnitude strike the most monstrous sacrileges." 102

$95 \quad$ CJ I.5.8.pr., trans. Frier (2016, 196-7): “[...] sciant se esse haereticos apollinaristas: apollinaris enim facinorosissimam sectam eutyches et dioscorus mente sacrilega sunt secuti [they shall know that they are Apollinarian heretics; for Eutyches and Dioscorus sacrilegiously pursued the most criminal sect of Apollinaris]."

96 CJ I.5.8.1, trans. Frier (2016, 197): "Ideoque hi omnes, qui apollinaris vel eutychetis perversitatem sequuntur, illis poenis, quae divorum retro principum constitutionibus contra apollinaristas vel serenitatis nostrae postmodum sanctione contra eutychianistas vel hac ipsa augustissima lege contra eosdem decretae sunt, noverint se esse plectendos [Therefore, all those who follow the perversity of Apollinaris or Eutyches shall know that they shall be stricken with the penalties that have been decreed by the constitutions of divine emperors of the past against the Apollinarians, or by the recent decree of Our Serenity against the Eutychians, or by this most august law against the same heretics]."

CJ I.5.8.1, trans. Frier (2016, 197): “[...] Apollinaristae, hoc est Eutychianistae quibus etsi est in appellatione diversitas, tamen in haeresis pravitate coniunctio, et dispar quidem nomen, sed idem sacrilegium [...]."

98 CJ I.5.8.2, forbidding the heretics from creating a parallel church hierarchy by appointing their own priests and bishops; I.5.8.3: banning the construction of churches or monasteries by "apollinaristae vel eutychianistae"; I.5.8.6, banning "Apollinarians or Eutychians" from imperial service; I.5.8.8, denying the right of assembly to "Apollinarians or Eutychians."

102 CJ I.5.8.pr., trans. Frier (2016, 199). 


\section{References}

Abramowski, Luise, and Alan E. Goodman, eds. 1972. A Nestorian Collection of Christological Texts: Cambridge University Library Ms. Oriental 1319. Vol. II. Cambridge: Cambridge University Press.

Ames, Christine Caldwell. 2015. Medieval Heresies: Christianity, Judaism, and Islam. Cambridge: Cambridge University Press.

Amirav, H. 2015. Authority and Performance: Sociological Perspectives on the Council of Chalcedon (AD 451). Göttingen: Vandenhoeck \& Ruprecht.

Armitage, J. M. 2005. A Twofold Solidarity: Leo the Great's Theology of Redemption. Strathfield: St Pauls Publications in Association with the Centre for Early Christian Studies.

Berzon, T. S. 2016. Classifying Christians: Ethnography, Heresiology, and the Limits of Knowledge in Late Antiquity. Oakland: University of California Press.

- 2017. "Strategies of Containment: Regulatory Rhetoric and Heretical Space in the Theodosian Code." Studies in Late Antiquity 1 (2): 124-49.

Blaudeau, Philippe. 2006. Alexandrie et Constantinople (451-491): de l'histoire à la géoecclésiologie. Bibliothèque des écoles françaises d'Athènes et de Rome. Rome: Ecole française de Rome.

Blümer, Wilhelm. 1991. Rerum eloquentia: christliche Nutzung antiker Stilkunst bei St. Leo Magnus. Europäische Hochschulschriften 51. Frankfurt am Main: Peter Lang.

Boulnois, Marie-Odile. 1994. Le paradoxe trinitaire chez Cyrille d'Alexandrie: herméneutique, analyses philosophiques et argumentation théologique. Collection des études augustiniennes. Série Antiquité 143. Paris: Institut d'etudes augustiennes.

Boyarin, Daniel. 2001. "Justin Martyr Invents Judaism." Church History 70 (3): 427-61.

—. 2007. Border Lines: The Partition of Judaeo-Christianity. Philadelphia: University of Pennsylvania Press.

Boyarin, Daniel, and Virginia Burrus. 2005. "Hybridity as Subversion of Orthodoxy? Jews and Christians in Late Antiquity." Social Compass 52 (4): 431-41.

Brauner, Christina. 2020. "Polemical Comparisons in Discourses of Religious Diversity: Conceptual Remarks and Reflexive Perspectives." Entangled Religions 11 (4). https://doi.or g/10.46586/er.11.2020.8692.

Brennecke, Hanns Christof. 1997. "Chalkedonense und Henotikon. Bemerkungen zum Prozess der östlichen Rezeption der christologischen Formel von Chalkedon." In Chalkedonense und Henotikon. Bemerkungen zum Prozess der östlichen Rezeption der christologischen Formel von Chalkedon, edited by Jan van Oort and J. Roldanus, 24-53. Patristische Arbeitsgemeinschaft 4. Leuven: Peeters.

—. 2010. "Das akakianische Schisma: Liberatus, Breviarium 15-18." Zeitschrift für Antikes Christentum 14 (1): 74-95.

Cameron, Averil. 2003. "How to Read Heresiology." Medieval and Early Modern Studies 33 (3): 471-92.

Caspar, Erich. 1930-1933. Geschichte des Papsttums von den Anfängen bis zur Höhe der Weltherrschaft. Tubingen: J. C. B. Mohr.

Casula, Lucio. 2002. Leone Magno: il Conflitto tra Ortodossia ed Eresia nel Quinto Secolo. Roma: Tiellemedia.

Chadwick, Henry. 1954. "Eucharist and Christology in the Nestorian Controversy." Journal of Theological Studies 2: 145-64. 
1955. "The Exile and Death of Flavian of Constantinople: A Prologue to the Council of Chalcedon." The Journal of Theological Studies 6: 17-34.

- 2001. The Church in Ancient Society from Galilee to Gregory the Great. Oxford: Oxford University Press.

Chew, Kathryn. 2006. "Virgins and Eunuchs: Pulcheria, Politics and the Death of Emperor Theodosius II." Historia: Zeitschrift Für Alte Geschichte 55 (2): 207-27.

Cohen, Jeremy. 1999. Living Letters of the Law: Ideas of the Jew in Medieval Christianity. Berkeley: University of California Press.

Cohen, S. 2015. "Schism and the Polemic of Heresy: Manichaeism and the Representation of Papal Authority in the Liber Pontificalis." JLA 8 (1): 195-230.

—. 2019. "'You Have Made Common Cause with Their Persecutors': Gelasius, the Language of Persecution, and the Acacian Schism." In Heirs of Roman Persecution: Studies on a Christian and Para-Christian Discourse in Late Antiquity, edited by É. Fournier and W. Mayer, 164-83. New York: Routledge.

Cooper, Kate. 2004. "Empress and Theotokos: Gender and Patronage in the Christological Controversy." Studies in Church History 39: 39-51.

Davis, Leo Donald. 1987. The First Seven Ecumenical Councils (325-787): Their History and Theology. Collegeville, Minn: Liturgical Press.

Davis, Stephen J. 2008. Coptic Christology in Practice Incarnation and Divine Participation in Late Antique and Medieval Egypt. Oxford Early Christian Studies. Oxford: Oxford University Press.

Di Berardino, Angelo. 2006. Nuovo dizionario patristico e di antichità cristiane. Genova: Istituto patristico Augustinianum.

Draguet, R. 1931. "La christologie d'Eutychès d'après les Actes du synode de Flavien." Byzantion 6: 441-57.

Eijk, P. J. van der. 1999. "Historical Awareness, Historiography and Doxography in Greek and Roman Medicine." In Ancient Histories of Medicine: Essays in Medical Doxography and Historiography in Classical Antiquity, edited by P. J. van der Eijk, 1-33. Boston: Brill.

Flower, Richard. 2011. "Genealogies of Unbelief: Epiphanius of Salamis and Heresiological Authority." In Unclassical Traditions, Vol. II: Perspectives from East and West in Late Antiquity, edited by C. Kelly, R. Flower, and M. S. Williams. Cambridge: Cambridge Philological Society.

. 2013. “'The Insanity of Heretics Must Be Restrained': Heresiology in the Theodosian Code." In Theodosius II: Rethinking the Roman Empire in Late Antiquity, edited by C. Kelly, 172-94. Cambridge: Cambridge University Press.

Frend, W. H. C. 1979. The Rise of the Monophysite Movement: Chapters in the History of the Church in the Fifth and Sixth Centuries. Cambridge: Cambridge University Press.

Frier, Bruce W., ed. 2016. The Codex of Justinian: A New Annotated Translation, with Parallel Latin and Greek Text Based on a. Translated by Justice Fred H. Blume. Cambridge: Cambridge University Press.

Fuhrmann, Horst, and Detlev Jasper. 2001. Papal Letters in the Early Middle Ages. Washington, D.C.: Catholic University of America Press.

Galtier, Paul. 1956. "Saint Cyrille et Apollinaire." Gregorianum 37 (4): 584-609.

Gavrilyuk, Paul L. 2004. The Suffering of the Impassible God the Dialectics of Patristic Thought. Oxford: Oxford University Press. 
Greatrex, G., ed. 2011. The Chronicle of Pseudo-Zachariah Rhetor: Church and War in Late Antiquity. Liverpool: Liverpool University Press.

Green, Bernard. 2008. The Soteriology of Leo the Great. Oxford: Oxford University Press.

Gregory, T. E. 1979. Vox Populi: Popular Opinion and Violence in the Religious Controversies of the Fifth Century A.D. Columbus: Ohio State University Press.

Grillmeier, Aloys. 1951. "Die theologische und sprachliche Vorbereitung der christologischen Formel von Chalkedon." In Das Konzil von Chalkedon: Geschichte und Gegenwart, edited by Aloys Grillmeier and Heinrich Bacht, 5-202. Würzburg: Echter-Verlag.

- 1975. Christ in Christian Tradition. Vol. 1: From the Apostolic Age to Chalcedon (451). Translated by John Bowden. 2nd ed. Atlanta: John Knox Press. . 1986. Christ in Christian Tradition. Vol. 2, Part 1: From Chalcedon to Justinian I. London: Mowbray.

Günther, Otto, ed. 1895-1898. Epistulae Imperatorum Pontificum Aliorum Inde ab a. CCCLXVII usque DLIII datae Avellana Quae Dicitur Collectio. CSEL 35. 1-2. Vienna.

Gwynn, David M. 2007. The Eusebians: The Polemic of Athanasius of Alexandria and the Construction of the "Arian Controversy". Oxford: Oxford University Press.

- 2009. "The Council of Chalcedon and the Defintion of Christian Tradtition." In Chalcedon in Context: Church Councils 400-700, edited by Richard Price and Mary Whitby, 7-26. Liverpool: Liverpool University Press.

— 2010. "Archaeology and the 'Arian Controversy' in the Fourth Century." Late Antique Archaeology 6 (1): 229-63.

Haas, Christopher. 1993. "Patriarch and People: Peter Mongus of Alexandria and Episcopal Leadership in the Late Fifth Century." Journal of Early Christian Studies 1 (3): 297-316.

Halleux, André de. 1976a. "La définition christologique à Chalcédoine (Première partie)." Revue théologique de Louvain 7 (1): 3-23.

—. 1976b. "La définition christologique à Chalcédoine (suite)." Revue théologique de Louvain 7 (2): 155-70.

Harkins, Franklin T. 2005. "Nuancing Augustine's Hermeneutical Jew: Allegory and Actual Jews in the Bishop's Sermons." Journal for the Study of Judaism in the Persian, Hellenistic, and Roman Period 36 (1): 41-64.

Holum, Kenneth G. 1982. Theodosian Empresses: Women and Imperial Dominion in Late Antiquity. Berkeley: University of California Press.

Humfress, C. 2007. Orthodoxy and the Courts in Late Antiquity. Oxford: Oxford University Press. . 2008. "Citizens and Heretics: Late Roman Lawyers on Christian Heresy." In Heresy and Identity in Late Antiquity, edited by E. Iricinschi and H. M. Zellentin, 128-42. Tubingen: Mohr Siebeck.

Hunt, Edmund. 1957. St. Leo the Great: Letters. FOTC 34. New York: Catholic University of America Press.

Inglebert, H. 2001. Interpretatio christiana: les mutations des savoirs (cosmographie, géographie, ethnographie, histoire) dans l'Antiquité chrétienne (30-630 après J.-C.). Paris: Institut d'études augustiniennes.

Iricinschi, Eduard, and Holger M. Zellentin. 2008. "Making Selves and Marking Others: Identity and Late Antique Heresiologies." In Heresy and Identity in Late Antiquity, edited by Eduard Iricinschi and Holger M. Zellentin, 1-29. Tübingen: Mohr Siebeck. 
King, Karen L. 2008. "Social and Theological Effects of Heresiological Discourse." In Heresy and Identity in Late Antiquity, edited by Eduard Iricinschi and Holger M. Zellentin, 28-49. Tübingen: Mohr Siebeck.

Le Boulluec, Alain. 1985. La notion d'hérésie dans la litterature grecque, IIe-IIIe siècles. Vol. II. Paris: Études augustiniennes.

Lim, Richard. 2008. "The Nomen Manichaeorum and Its Uses in Late Antiquity." In Heresy and Identity in Late Antiquity, edited by Eduard Iricinschi and Holger M. Zellentin, 142-67. Tübingen: Mohr Siebeck.

Loofs, Friedrich. 1914. Nestorius and His Place in the History of Christian Doctrine. Cambridge: Cambridge University Press.

Loon, Hans van. 2009. The Dyophysite Christology of Cyril of Alexandria. Leiden: Brill.

Louth, A. 2015. "Christology in the East from the Council of Chalcedon to John Damascene." In The Oxford Handbook of Christology, edited by F. Murphy. Oxford: Oxford University Press.

Lyman, J. Rebecca. 1993. "A Topography of Heresy: Mapping the Rhetorical Creation of Arianism." In Arianism After Arius: Essays on the Development of the Fourth Century Trinitarian Conflicts, edited by Michel R. Barnes and Daniel H. Williams, 45-62. Edinburgh: T \& T Clark.

_ 1997. "The Making of a Heretic: The Life of Origen in Epiphanius Panarion 64." Studia Patristica 31: 445-51.

. 2007. "Heresiology: The Invention of 'Heresy' and 'Schism'." In The Cambridge History of Christianity 2: Constantine to C. 600, edited by Augustine Casiday and Frederick W. Norris, 296-313. Cambridge University Press.

McGuckin, John Anthony. 2004. St. Cyril of Alexandria: The Christological Controversy. Crestwood, N.Y: St. Vladimir's Seminary Press.

McShane, Philip. 1979. La Romanitas et le Pape Léon le Grand: l'apport culturel des institutions impériales à la formation des structures ecclésiastiques. Paris: Desclée.

Meyendorff, John. 1989. Imperial Unity and Christian Divisions: The Church 450-680 AD. St. Vladimir's Seminary Press.

Millar, F. 2006. A Greek Roman Empire: Power and Belief Under Theodosius II (408/450). Berkeley: University of California Press.

Murphy, Francesca A. 2015. The Oxford Handbook of Christology. Oxford: Oxford University Press.

Mühlenberg, Ekkehard. 1997. "Chalkedon: Geschichte und Aktualität: Studien zur Rezeption der christologischen Formel von Chalkedon." In Studien der Patristischen Arbeitsgemeinschaft, edited by J. Gerhard van Oort and J. Roldanus, 1-23. Leuven: Peeters.

Neil, Bronwen. 2009. Leo the Great. London: Routledge.

— 2016. "Papal Letters and Letter Collections." In Late Antique Letter Collections: A Critical Introduction and Reference Guide, edited by Cristiana Sogno, Bradley K. Storin, and Edward J. Watts, 449-66. Oakland: University of California Press.

Pelikan, Jaroslav Jan. 1978. Growth of Medieval Theology (600-1300). Vol. 2. Christian Tradition. Chicago: University of Chicago Press.

Pourkier, Aline. 1992. L'hérésiologie chez Épiphane de Salamine. Christianisme antique 4. Paris: Beauchesne. 
Price, Richard. 2009. "The Council of Chalcedon (451): A Narrative.” In Chalcedon in Context: Church Councils 400-700, edited by Richard Price and Mary Whitby, 70-91. Liverpool: Liverpool University Press.

Price, Richard, and Michael Gaddis, eds. 2005. The Acts of the Council of Chalcedon. 3 vols. Liverpool: Liverpool University Press.

Robertson, Paul. 2018. "He Polemic of Individualized Appellation in Late Antiquity." Studies in Late Antiquity 2 (2): 180-214.

Runia, D. T. 1999. "What Is Doxography." In Ancient Histories of Medicine: Essays in Medical Doxography and Historiography in Classical Antiquity, edited by P. J. van der Eijk, 33-55. Boston: Brill.

Schäublin, C. 1974. Untersuchungen zu Methode und Herkunft der Antiochenischen Exegese. Cologne-Bonn: P. Hanstein.

Schwartz, Eduard. 1927. "Die Kaiserin Pulcheria auf der Synode von Chalkedon." In Festgabe für Adolf Jülicher, 203-12. Tübingen: Mohr.

— 1929. "Der Prozess des Eutyches." Sitzungsberichte der Bayerischen Akademie der Wissenschaften, Phil.-hist 5: 1-93.

. 1936. "Die Kanonessammlungen der alten Reichskirche." Zeitschrift der SavignyStiftung für Rechtsgeschichte. Kanonistische Abteilung 25 (1): 1-114.

Sillett, Helen Marie. 1999. "Culture of Controversy: The Christological Disputes of the Early Fifth Century." PhD diss., Berkeley: University of California.

Silva-Tarouca, K. C. 1926. "Die Quellen der Briefsammlungen Papst Leos des Großen, ein Beitrag zur Frage nach den Quellen der ältesten Papstbriefsammlungen." In Papsttum und Kaisertum: Forschungen zur politischen Geschichte und Geisteskultur des Mittelalters, edited by Albert Brackmann, 23-47. Munich: Scientia.

. 1931. "Nuovi studi sulle antiche lettere dei papi." Gregorianum 12 (4): 1-56, 349-425, 547-98.

Simonetti, Manlio. 1985. Lettera e/o allegoria : un contributo alla storia dell'esegesi patristica. Rome: Institutum Patristicum "Augustinianum".

- 2014. "Monophysitism." In The Encyclopedia of Ancient Christianity, edited by Angelo Di Berardino, 3:826-29. Downers Grove: InterVarsity Press.

Steckel, Sita. 2018. "Verging on the Polemical. Towards an Interdisciplinary Approach to Medieval Religious Polemic." Medieval Worlds 7: 2-60.

Thiel, Andreas, ed. 1868. Epistolae Romanorum Pontificum genuinae et quae ad eos scriptae sunt: Tomus 1. a S. Hilaro usque ad Pelagium II. Braunsberg: E. Peters.

Urbina, Ignatio Ortiz de. 1951. "Das Symbol von Chalkedon. Sein Text, sein Werden, seine dogmatische Bedeutung." In Das Konzil von Chalkedon: Geschichte und Gegenwart, edited by Alois Grillmeier, Heinrich Bacht, and Heinrich Bacht, 389-418. I. Würzburg: EchterVerlag.

Uthemann, Karl-Heinz. 2001. "Zur Rezeption des Tomus Leonis in und nach Chalkedon. Wider den dogmenhistorischen Begriff 'strenger Chalkedonismus.'." Studia Patristica 34 (1): 572-604.

— 2007. "History of Christology to the Seventh Century." In The Cambridge History of Christianity: Volume 2: Constantine to C. 600, edited by Augustine Casiday and Frederick W. Norris. Vol. 2. Cambridge: Cambridge University Press.

Vranić, Vasilije. 2008. "The Christology of Eutyches at the Council of Constantinople 448." Philotheos 8: 208-21. 
Wessel, Susan. 2004. Cyril of Alexandria and the Nestorian Controversy: The Making of a Saint and of a Heretic. New York: Oxford University Press.

- 2008. Leo the Great and the Spiritual Rebuilding of a Universal Rome. Leiden: Brill.

Whitby, Michael, ed. 2000. The Ecclesiastical History of Evagrius Scholasticus. Liverpool: Liverpool University Press.

Wiles, Maurice. 1991. "Orthodoxy and Heresy." In Early Christianity: Origins and Evolution to AD 600: In Honour of W.H.C. Frend, edited by Ian Hazlett, 198-207. Nashville: Abingdon Press.

Williams, Michael Stuart. 2017. The Politics of Heresy in Ambrose of Milan. Community and Consensus in Late-Antique Christianity. Cambridge: Cambridge University Press.

Williams, Rowan. 1989. "Does It Make Sense to Speak of Pre-Nicene Orthodoxy?" In The Making of Orthodoxy: Essays in Honour of Henry Chadwick, edited by Rowan Williams, 1-23. Cambridge: Cambridge University Press.

Young, Frances M. 1971. "A Reconsideration of Alexandrian Christology." Journal of Ecclesiastical History 22 (2): 103-14. 